OPEN ACCESS

Edited by:

Hans-Peter Kaul,

University of Natural Resources and Life Sciences, Vienna, Austria

Reviewed by:

Othmane Merah,

Université de Toulouse, France

Rajeev Nayan Bahuguna, Indian Agricultural Research Institute

(ICAR), India

*Correspondence: Alejandro del Pozo adelpozo@utalca.cl

Specialty section: This article was submitted to Crop and Product Physiology, a section of the journal Frontiers in Plant Science

Received: 09 December 2018 Accepted: 18 March 2019

Published: 05 April 2019

Citation:

Méndez-Espinoza AM, Romero-Bravo S, Estrada F, Garriga M, Lobos GA, Castillo $D$, Matus I, Aranjuelo I and del Pozo A (2019) Exploring Agronomic and Physiological Traits Associated With the Differences in Productivity Between Triticale and Bread Wheat

in Mediterranean Environments.

Front. Plant Sci. 10:404.

doi: 10.3389/fpls.2019.00404

\section{Exploring Agronomic and} Physiological Traits Associated With the Differences in Productivity Between Triticale and Bread Wheat in Mediterranean Environments

Ana María Méndez-Espinoza', Sebastián Romero-Bravo ${ }^{1,2}$, Félix Estrada1, Miguel Garriga1, Gustavo A. Lobos ${ }^{1,3}$, Dalma Castillo ${ }^{4}$, Iván Matus ${ }^{4}$, Iker Aranjuelo ${ }^{5}$ and Alejandro del Pozo ${ }^{1 *}$

${ }^{1}$ Centro de Mejoramiento Genético y Fenómica Vegetal, Facultad de Ciencias Agrarias, Universidad de Talca, Talca, Chile, ${ }^{2}$ Facultad de Ciencias Agrarias y Forestales, Universidad Católica del Maule, Curicó, Chile, ${ }^{3}$ Núcleo Científico Multidisciplinario-DI, Universidad de Talca, Talca, Chile, ${ }^{4}$ CRI-Quilamapu, Instituto de Investigaciones Agropecuarias, Chillán, Chile, ${ }^{5}$ Instituto de Agrobiotecnología, Consejo Superior de Investigaciones Científicas, Universidad Pública de Navarra, Navarra, Spain

In Mediterranean climates soil water deficit occurs mainly during the spring and summer, having a great impact on cereal productivity. While previous studies have indicated that the grain yield (GY) of triticale is usually higher than bread wheat (Triticum aestivum L.), comparatively little is known about the performance of these crops under water-limited conditions or the physiological traits involved in the different yields of both crops. For this purpose, two sets of experiments were conducted in order to compare a high yielding triticale (cv. Aguacero) and spring wheat (cvs. Pandora and Domo). The first experiment, aiming to analyze the agronomic performance, was carried out in 10 sites located across a wide range of Mediterranean and temperate environments, distributed between $33^{\circ} 34^{\prime}$ and $38^{\circ} 41^{\prime} \mathrm{S}$. The second experiment, aiming to identify potential physiological traits linked to the different yields of the two crops, was conducted in two Mediterranean sites (Cauquenes and Santa Rosa) in which crops were grown under well-watered (WW) and water-limited (WL) conditions. The relationship between GY and the environmental index revealed that triticale exhibited a higher regression coefficient (Finlay and Wilkinson slope), indicating a more stable response to the environment, accompanied by higher yields than bread wheat. Harvest index was not significantly different between the two cereals, but triticale had higher kernels per spike (35\%) and 1000 kernel weight (16\%) than wheat, despite a lower number of spikes per square meter. The higher yield of triticale was linked to higher values of chlorophyll content, leaf net photosynthesis (An), the maximum rate of electron transport (ETRmax), the photochemical quantum yield of PSII $[Y(I I)]$ and leaf water-use efficiency. GY was positively correlated with $\mathrm{Ci}$ at anthesis and $\Delta^{13} \mathrm{C}$ in both species, as well as with gs at anthesis in triticale, but negatively correlated with non-photochemical fluorescence quenching and quantum 
yield of non-photochemical energy conversion at grain filling in wheat. These results revealed that triticale presented higher photosynthetic rates that contributed to increase plant growth and yield in the different environments, whereas wheat showed higher photoprotection system in detriment of assimilate production.

\section{Keywords: cereals, grain yield, leaf gas exchange, chlorophyll fluorescence, photosynthesis}

\section{INTRODUCTION}

Triticale ( $\times$ Triticosecale Wittmack) is a hybrid originating from a cross between wheat (Triticum spp.) and rye (Secale cereale). The global cropping area for triticale in 2016 was $4,157,018$ ha and the average grain yield $(\mathrm{GY})$ is $3.66 \mathrm{t}$ $\mathrm{ha}^{-1}$ (FAO, 2018). The largest producers are Poland (1.40 million ha) followed by Belarus and Germany (0.49 and 0.39 million ha, respectively). While triticale is cultivated on only 23,144 ha in Chile (compared to 236,415 ha for wheat), its average grain yield per hectare (GY) is nearly the same as that obtained for wheat $\left(6.1\right.$ and $6.0 \mathrm{t} \mathrm{ha}^{-1}$ respectively; ODEPA, 2018). Comparative studies among cereals indicate that the GY of triticale is usually higher than bread (Triticum aestivum L.) or durum (Triticum durum) wheat. Indeed, field trials conducted in Australia, Spain, Sardinia, Lebanon and Tunisia, have shown that triticale yields tend to be greater than bread or durum wheat (Giunta et al., 1993; LópezCastañeda and Richards, 1994; Villegas et al., 2010). In the high-yielding environments of the United Kingdom, the average GY of triticale cultivars was also larger than wheat cultivars (Roques et al., 2017).

The higher yield of triticale has been attributed to higher radiation use efficiency (RUE), greater biomass at anthesis and maturity, and a larger number of grains per spike compared to bread wheat (Estrada-Campuzano et al., 2012). Also, triticale exhibited higher biomass, RUE and stomatal conductance (gs) compared to durum wheat under Mediterranean conditions (Motzo et al., 2015). In addition, Planchon (1979) reported higher net photosynthesis (An) and water use efficiency (WUE) in triticale compared to bread and durum wheat plants grown in pots under natural conditions, and Winzeler et al. (1989) reported higher dry matter (DM) accumulation in triticale and lower leaf respiration rates than wheat under controlled environment conditions.

In Mediterranean climates, soil water deficit occurs mainly during the spring and summer, which has a great impact on cereal productivity (Trnka et al., 2014; Hochman et al., 2017). Thus, under rain-fed conditions, the grain filling stage of cereals generally occurs under drought stress (Stanca et al., 2003; Dolferus et al., 2013; Sanchez-Bragado et al., 2014; del Pozo et al., 2016; Hochman et al., 2017), which limits photosynthesis and the production of photosynthetic assimilates that are directly transferred to the grain (Schnyder, 1993). The assimilates necessary for grain filling are provided by photosynthesis in the leaves and spike (Tambussi et al., 2007; Maydup et al., 2010; Sanchez-Bragado et al., 2014), and the redistribution of stored reserves in vegetative tissues during the pre- and/or post-anthesis stages that are translocated to the growing grains (Schnyder, 1993; Yang and Zhang, 2006). Consequently, differences in leaf gas exchange and the performance of the photosynthetic apparatus during anthesis and grain filling may explain the greater productivity of triticale compared to wheat in Mediterranean environments.

At leaf level, leaf water potential $(\Psi)$, net $\mathrm{CO}_{2}$ assimilation (An), stomatal conductance (gs), and transpiration (E) decrease under water-limited conditions, leading to changes in instantaneous water-use efficiency $(\mathrm{An} / \mathrm{E})$ and intrinsic water-use efficiency (An/gs) in cereals (Tambussi et al., 2007; Sikder et al., 2015; Liu et al., 2017). Also, drought stress can affect the performance of Photosystem II and the electron transport chain, leading to a non-stomatal limitation of photosynthesis (Chaves and Oliveira, 2004). Chlorophyll $a$ fluorescence variables and derived parameters obtained from dark-adapted and light-exposed leaves have been used to assess changes in the photosynthetic apparatus as a result of stress (Beer and Björk, 2000; Fracheboud and Leipner, 2003; Harbinson and Rosenqvist, 2003; Estrada et al., 2015). Indeed, differences in the activity of the photosynthetic apparatus among 10 genotypes of triticale have been reported previously, but only for plants grown under well-watered conditions in a glasshouse (Hura et al., 2009). However, to the best of our knowledge, direct comparisons of chlorophyll parameters between wheat and triticale grown in Mediterranean environments under well-watered and water-limited conditions have not been reported.

Carbon isotope discrimination $\left(\Delta^{13} \mathrm{C}\right)$ is a valuable trait that integrates the impact of growing conditions on the stomatal opening and carbon assimilation in a large period of time (Monneveux et al., 2006). It also provides indirect information about the efficiency of the water used by the crop (Araus et al., 2008; Blum, 2009). $\Delta^{13} \mathrm{C}$ in kernels can be positive or negatively correlated with GY depending on soil water availability [del Pozo et al., 2016 (for wheat); Munjonji et al., 2017 (for triticale)]. Surprisingly, direct comparison of $\Delta^{13} \mathrm{C}$ in kernels between wheat and triticale, in field grown plants, has not been reported, so far.

This article reports the results of two sets of experiments aiming to compare the performance of a high yielding triticale (cv. Aguacero) and spring wheat (cvs. Pandora and Domo) in a wide range of environments. The objectives of this work were to: (i) evaluate the productivity of triticale and wheat in Mediterranean and temperate environments of central-south of Chile; and (ii) study the performance of the leaf photosynthetic characteristics in the two species, during the grain filling period, and its relationship with agronomic traits, in two contrasting 
Mediterranean environments, under well-watered and water-limited conditions.

\section{MATERIALS AND METHODS}

\section{Plant Material, Growing Conditions, and Experimental Design}

In this investigation, high yielding triticale (cv. Aguacero) and spring wheat (cvs. Pandora and Domo) were studied in two sets of field experiments.

\section{Experiment 1}

Field trials comparing top high yielding cultivars of spring triticale (cv. Aguacero-INIA) and spring bread wheat (PandoraINIA and Domo-INIA) were conducted at 10 different localities between $33^{\circ} 34^{\prime}$ and $38^{\circ} 41^{\prime} S$ (in 2004 and 2005), representing the wide range of Mediterranean and temperate environments where bread wheat is cultivated in Chile. The date of sowing for each experiment was as recommended for each locality and it ranged from the end of May to the middle of September. The seed rate was $20 \mathrm{~g} \mathrm{~m}^{-2}$ for all cultivars and the plot size was $2 \mathrm{~m} \times 1 \mathrm{~m}$, with the experimental design at each site being randomized block. Crop management included fertilization and weed control in order to provide the optimum growing conditions to all cultivars. Also, irrigation was used in some of the localities. These trials are regularly conducted by INIA for testing cultivars used by farmers and new advanced lines.

\section{Experiment 2}

Triticale cv. Aguacero and bread wheat cv. Pandora were evaluated at two Mediterranean sites, Cauquenes $\left(35^{\circ} 58^{\prime} \mathrm{S}\right.$, $72^{\circ} 17^{\prime} \mathrm{W}$; 177 m.a.s.l.) and Santa Rosa $\left(36^{\circ} 32^{\prime}\right.$ S, $71^{\circ} 55^{\prime}$ W; 220 m.a.s.l.), under well-watered (WW) and water-limited (WL) conditions, in 2015 and 2016. In 2014 the trial was conducted only at Santa Rosa under WW condition. Cauquenes corresponds to the Mediterranean drought-prone area of Chile and precipitation was 580 and $430 \mathrm{~mm}$ in 2015 and 2016, respectively; the soil correspond to a granitic classified as Ultic Palexeralfs. Santa Rosa is an irrigated area and the annual precipitation was 979 and $485 \mathrm{~mm}$ in 2015 and 2016, respectively; the soil was a sandy loam, humic haploxerand (Andisol). The $\mathrm{WL}$ condition corresponded to rainfed at Cauquenes and Santa Rosa. For the WW condition, sprinkler irrigation was used in Cauquenes and furrow irrigation in Santa Rosa: two to four irrigations after the flag leaf stage (Z37). The sowing rate was $20 \mathrm{~g} \mathrm{~m}^{-2}$ and sowing dates in both years were 18 May at Cauquenes and 29 July at Santa Rosa. Plots consisted of five rows of $2 \mathrm{~m}$ in length and $0.2 \mathrm{~m}$ distance between rows, in a randomized block design with four replications. Plots received a complete fertilization consisting of: $260 \mathrm{~kg} \mathrm{ha}^{-1}$ of ammonium phosphate $\left(46 \% \mathrm{P}_{2} \mathrm{O}_{5}\right.$ and $\left.18 \% \mathrm{~N}\right), 90 \mathrm{~kg} \mathrm{ha}^{-1}$ of potassium chloride $\left(60 \% \mathrm{~K}_{2} \mathrm{O}\right), 200 \mathrm{~kg} \mathrm{ha}^{-1}$ of sul-po-mag $\left(22 \% \mathrm{~K}_{2} \mathrm{O}\right.$, $18 \% \mathrm{MgO}$ and $22 \% \mathrm{~S}), 10 \mathrm{~kg} \mathrm{ha}^{-1}$ of boronatrocalcite $(11 \%$ B) and $3 \mathrm{~kg} \mathrm{ha}^{-1}$ of zinc sulfate $(35 \% \mathrm{Zn})$. During tillering an extra $153 \mathrm{~kg} \mathrm{ha}^{-1}$ of $\mathrm{N}$ was applied. Weeds were controlled with recommended herbicides and no fungicides were needed.
Leaf sampling was always carried out in leaves in which gas exchange analyses and chlorophyll fluorescence analyses were determined. The leaf samples were plunged immediately into liquid nitrogen and stored at $-80^{\circ} \mathrm{C}$, for later chlorophyll and proline determinations.

\section{Agronomic Evaluations}

At maturity, the number of spikes per $\mathrm{m}^{2}$ (SM2) was determined in a $1 \mathrm{~m}$ length section of an inside row of the plot. The aboveground DM and grain biomass was determined in the same $1 \mathrm{~m}$ length. Then, harvest index (HI) was calculated and the number of kernels per spike (KS) and 1000 kernel weight (TKW) were determined from the spikes harvested. Plant height $(\mathrm{PH})$ was measured from the base of the plant to the top of the spike (without awns). Finally, GY was estimated from $2 \mathrm{~m}^{2}$ in Experiment 1 and from the $1 \mathrm{~m}$ length in Experiment 2.

\section{Leaf Water Potential, Leaf Gas Exchange, and Chlorophyll a Fluorescence}

Physiological traits were determined at Cauquenes and Santa Rosa during 2014-2016. Leaf water potential, gas exchange, and chlorophyll fluorescence were evaluated on three flag leaves per plot, at anthesis and in grain filling. Leaf water potential $\left(\Psi_{\mathrm{L}}\right)$ was determined in the three flag leaves placed together in a pressure chamber (PMS Instrument, Co., United States).

An, gs, internal $\mathrm{CO}_{2}$ concentration $(\mathrm{Ci})$, and transpiration (E) were determined at light saturation, using a portable open system infra-red gas analyzer (CIRAS-2 model, PP Systems, Amesbury, $\mathrm{MA}$, United States) with a $0.250 \mathrm{~L} \mathrm{~min}^{-1}$ flow rate, $380 \mathrm{ppm} \mathrm{CO}_{2}$ and leaf temperature at $25^{\circ} \mathrm{C}$. Measurements were performed between 12:00 and 16:00 on sunny days at a photon flux density of $1,500 \mathrm{mmol} \mathrm{m} \mathrm{m}^{-2} \mathrm{~s}^{-1}$, using a broad leaf cuvette $\left(1.7 \mathrm{~cm}^{2}\right.$ of leaf area). The instantaneous WUE was calculated as An/E and the intrinsic WUE as An/gs.

Chlorophyll fluorescence of dark and light-acclimated leaves (same leaf samples as used for the leaf gas exchange) was measured with a portable PAM-2500 fluorometer (Walz, Germany) with Leaf-Clip Holder 2030-B (measurement angle $60^{\circ}$ ). First, each leaf was dark-acclimated for 20 min using a dark leaf clip (DLC-8) in order to determine the minimum (Fo) and maximum (Fm) fluorescence in the dark-adapted state, and the maximum photochemical quantum yield of PSII $[\mathrm{Fv} / \mathrm{Fm}=(\mathrm{Fm}-\mathrm{Fo}) / \mathrm{Fm}]$. With the equipment programmed to measure in amplitude modulated pulse mode, the clip was opened and after $30 \mathrm{~min}$ of light acclimation, fast light curves (FLCs) were developed considering 10 pulses every $6 \mathrm{~s}$, which increased from 0 to $2000 \mu \mathrm{mol} \mathrm{m}^{-2} \mathrm{~s}^{-1}$. After each light level, the equipment delivered a light pulse in far-red for $3 \mathrm{~s}$ and then a saturation pulse of actinic light $\left(16,500 \mu \mathrm{mol} \mathrm{m}^{-2} \mathrm{~s}^{-1}\right)$ in order to determine the minimum $\left(\mathrm{Fo}^{\prime}\right)$ and maximum $\left(\mathrm{Fm}^{\prime}\right)$ chlorophyll fluorescence yield when PSII reaction centers were in the open state. Using an FLC light intensity of $1,500 \mu \mathrm{mol} \mathrm{m} \mathrm{m}^{-2} \mathrm{~s}^{-1}$, the following parameters were calculated: $\mathrm{Y}(\mathrm{II})$ : effective photochemical quantum yield of PSII [(Fm'$\left.\mathrm{F}) / \mathrm{Fm}^{\prime}\right]$, where $\mathrm{F}$ is the fluorescence shortly before a saturating 
pulse; $\mathrm{Y}(\mathrm{NPQ})$ : quantum yield of non-photochemical energy conversion in PSII due to down-regulation of the light-harvesting function; $\mathrm{Y}(\mathrm{NO})$ : quantum yield of non-photochemical energy conversion in PSII other than that caused by down-regulation of the light-harvesting function; and NPQ: non-photochemical fluorescence quenching $\left[\left(\mathrm{Fm} / \mathrm{Fm}^{\prime}\right)-1\right]$. In addition, the fitting of the FLC according to Eilers and Peeters (1988) allowed determination of the following parameters: Alpha: initial slope of the light curve, related to the maximum photosynthetic yield; ETRmax: maximum rate of electron transport; and IK: the PAR value at the intersection of alpha and ETRmax.

\section{Chlorophyll and Proline Determination}

The same flag leaves used for the non-destructive physiological evaluations were collected and stored at $-80^{\circ} \mathrm{C}$ until use. The leaf tissue was ground with liquid nitrogen and $100 \mathrm{mg}$ of each sample was taken for chlorophyll and proline determination. The pigments were extracted in $1.5 \mathrm{ml} \mathrm{N}, \mathrm{N}$-dimethylformamide and stored in the dark at $4^{\circ} \mathrm{C}$ for $48 \mathrm{~h}$ (Moran and Porath, 1980). Absorbance of the extracts was measured at 664.5 and $647.0 \mathrm{~nm}$ using the simultaneous equations described by Inskeep and Bloom (1985). Concentrations of chlorophyll a (Chla) and $b$ (Chlb) were expressed on a leaf weight basis (mg $\mathrm{g}$ $\mathrm{FW}^{-1}$ ). In addition, chlorophyll content was measured using a DUALEX sensor (Dualex Scientific, Force A, France) as a non-destructive measurement.

Proline concentration was determined according to the method of Bates et al. (1973) with minor modifications. The extraction was carried out with $2 \mathrm{ml}$ of $3 \% 5$-sulfosalicylic acid. This mixture was centrifuged at $7000 \mathrm{rpm}$ for $20 \mathrm{~min}$ and the supernatant was obtained. Acetic acid $(1 \mathrm{ml})$ and $1 \mathrm{ml}$ of ninhydrin reagent [ninhydrin $2.5 \%(\mathrm{w} / \mathrm{v})$, acetic acid $60 \%(\mathrm{v} / \mathrm{v})$, orthophosphoric acid $23.5 \%(\mathrm{v} / \mathrm{v})]$ were added to $1 \mathrm{ml}$ of supernatant. The mixture was kept in a hot water bath at $100^{\circ} \mathrm{C}$ for $45 \mathrm{~min}$ and placed on ice for $30 \mathrm{~min}$. After that, $1 \mathrm{ml}$ of toluene was added with the mixture being shaken for $1 \mathrm{~min}$ and centrifuged at $7000 \mathrm{rpm}$ for $10 \mathrm{~min}$. The organic phase was collected, and the proline concentration was quantified at $520 \mathrm{~nm}$ from a standard curve using L-proline. For the determinations, a UV/VIS T80+ (PG Instruments, United Kingdom) spectrophotometer and Eppendorf 5810R (Eppendorf, Germany) and Heraeus Fresco 17 (Thermo Scientific, United States) centrifuges were used.

\section{Stomatal Size and Density}

For both wheat and triticale, stomatal characterization was performed on the abaxial surface of mature flag leaves (sections from the middle to avoid differential thickness along the leaf), during the 2014 (WW) and 2015 (WW and WL) seasons in Santa Rosa. The characterization process consisted of removal of leaf hairs with transparent adhesive tape and coating the leaf with clear varnish (Bacelar et al., 2006; Guerfel et al., 2009). The dried stomatal impressions were carefully detached with adhesive tape attached to a slide (Ennajeh et al., 2010) and then three photographs were taken with the microscope (Motic BA310, China). The photographs were analyzed with the Matlab program, while the Motic Images Plus 2.0ML program was used to evaluate stomatal size. The number of stomata was counted in $1.27 \mathrm{~mm}^{2}$, equivalent to the diameter of the observed field of the image. For size, five stomata were selected in each image and length and width determination were performed.

\section{Carbon Isotope Discrimination}

The carbon $\left({ }^{13} \mathrm{C} /{ }^{12} \mathrm{C}\right)$ isotope ratio in kernels was determined using an elemental analyzer (ANCA-SL, PDZ Europa, United Kingdom) coupled with an isotope ratio mass spectrometer, at the Laboratory of Applied Physical Chemistry at Ghent University (Belgium). The ${ }^{13} \mathrm{C} /{ }^{12} \mathrm{C}$ ratios were expressed as carbon isotope composition: $\delta^{13} \mathrm{C}=\left(\left(\left({ }^{13} \mathrm{C} /{ }^{12} \mathrm{C}\right)_{\text {sample }} /\left({ }^{13} \mathrm{C} /{ }^{12} \mathrm{C}\right)_{\text {standard }}\right)-1\right)$, where sample refers to plant material and standard to the laboratory standards that have been calibrated against international standards from Iso-Analytical (Crewe, Cheshire, United Kingdom). The precision of $\delta^{13} \mathrm{C}$ analyses was $0.3 \%$. Further, the carbon isotope discrimination $\left(\Delta^{13} \mathrm{C}\right)$ in kernels was calculated as: $\Delta^{13} \mathrm{C}$ $(\% 0)=\left(\delta^{13} C_{a}-\delta^{13} C_{p}\right) /\left[1+\left(\delta^{13} C_{p}\right) / 1000\right]$, where a and $p$ refer to air and the plant, respectively (Farquhar et al., 1989). $\delta^{13} \mathrm{C}_{a}$ from the air was taken as $-8.0 \%$.

\section{Statistical Analysis and Calculations}

For physiological and yield-related traits, differences among genotypes $(\mathrm{G})$ and environments (E) were determined through analysis of variance (ANOVA) using Statgraphics Centurion XVII. In the ANOVA, site and water treatments were considered as environments. Regression analyses were performed between the GY of each cultivar and the mean GY of cultivars in each environment (environmental index; Finlay and Wilkinson, 1963). The regression coefficient (Finlay and Wilkinson slope) is a measure of yield adaptability (Calderini and Dreccer, 2002). For the comparison of regression lines, An, gs, and E were linearized with a logarithmic transformation.

For each trait (T), the relative differences (\%) were calculated considering water regimes $\left[\left(\mathrm{T}_{\mathrm{WW}}-\mathrm{T}_{\mathrm{WL}} / \mathrm{T}_{\mathrm{WW}}\right)\right]$ and species $\left[\left(\mathrm{T}_{\text {trit }}-\mathrm{T}_{\mathrm{wh}}\right) / \mathrm{T}_{\text {trit }}\right]$. Also, correlation and regression analysis were performed between physiological and agronomic traits. Furthermore, principal component analysis (PCA) was carried out using the physiological and agronomic traits of both water regimes and growing seasons (2015 and 2016).

\section{RESULTS}

\section{Grain Yield and Its Components}

The relationship between GY and the environmental index, determined in different locations in central Chile, revealed significant differences among the slopes $(P<0.01)$ and intercept $(P<0.001)$; triticale exhibited a higher regression coefficient (Finlay and Wilkinson slope), indicating a more stable response to the environment, accompanied by higher yields than bread wheat, even in extreme environments where the average yield was about $200 \mathrm{~g} \mathrm{~m}^{-2}$ (Figure 1). The linear relationship between GY and the number of grains per $\mathrm{m}^{2}$ showed a higher GY in triticale than wheat at any level of grain number $(P<0.001$ for both cereals) (Figure 2), as a consequence of the larger 


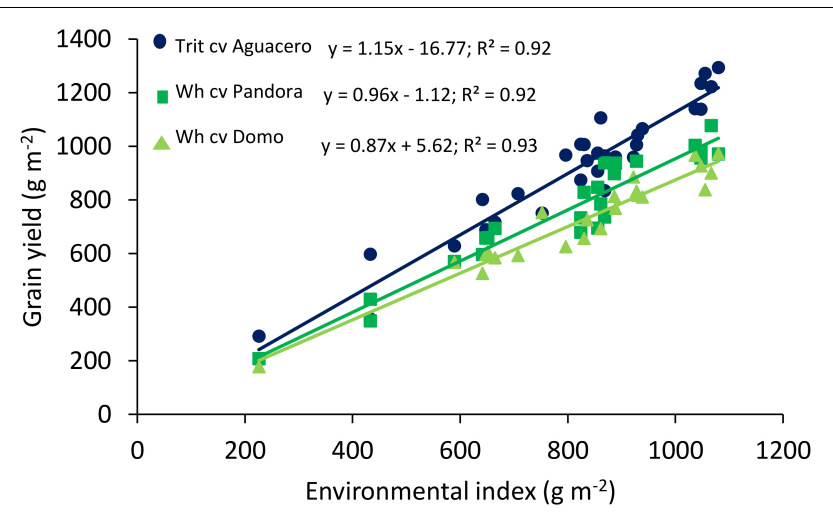

FIGURE 1 | Relationships between the environmental index and grain yield of spring wheat (cv. Pandora-INIA) and triticale (cv. Aguacero-INIA). Data are from 10 localities in 2004 and 2005 (eight Mediterranean and two temperate areas), and two localities (Cauquenes and Santa Rosa), under well-watered and water-deficit conditions, in 2014,2015 , and 2016. Also, data from Mellado et al. (2005) comparing triticale cv. Aguacero-INIA and the spring wheat cv. Domo at nine localities in 2001 and 2002 were included in the analysis. The comparison of the regression lines indicated significant difference among the slopes $(P<0.01)$ and intercepts $(P<0.0001)$.

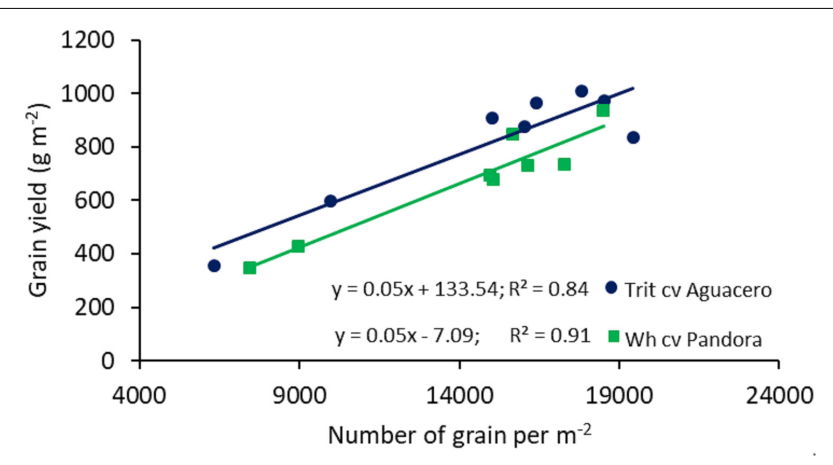

FIGURE 2 | Relationships between the number of grains per $\mathrm{m}^{-2}$ and grain yield of spring wheat (Cv. Pandora-INIA) and triticale (cv. Aguacero-INIA). Data are from two localities (Cauquenes and Santa Rosa), under well-watered and water-deficit conditions, in 2014, 2015, and 2016. The comparison of the regression lines indicated not significant difference between the slopes $(P=0.7359)$, but significant difference between intercepts $(P<0.001)$.

grain size in triticale. The comparison of the regression lines do not shows differences in the slopes, but it was significant between the intercepts.

The evaluations conducted at Cauquenes and Santa Rosa under WW and WL conditions in 2014, 2015 and 2016, revealed that triticale produced on average $21.6 \%$ more aboveground biomass and had a 20.2\% larger GY than bread wheat (Table 1). The HI was not significantly different $(P>0.05)$ between the two cereals, but triticale had significantly higher $(P<0.001)$ KS (35\%) and TKW (16\%) than wheat, even though lower SM2 number (Table 1). The environmental effect was highly significant $(P<0.001)$ for all agronomic traits and the $\mathrm{G} \times \mathrm{E}$ interaction was significant for TKW (Table 1). Under rainfed conditions in Cauquenes, the biomass production and GY were exceptionally high in 2015 (biomass: 1872 and $1745 \mathrm{~g} \mathrm{~m}^{-2}$; GY: 835 and $736 \mathrm{~g} \mathrm{~m}^{-2}$ in triticale and wheat, respectively), due to the large amount of precipitation during October and November, and therefore the differences between WW and WL conditions were minor. $\mathrm{PH}$ was significantly different between the two crops $(P>0.001)$ and environments $(P>0.000)$; triticale was on average $21.1 \%$ higher than wheat, and this pattern was observed in all the environments (Table 1).

In 2016, the year where the water deficit was more pronounced, the relative differences between water regimes (WW and WL) for agronomic traits (GY, SM2, KS, and TKW) were larger in triticale, particularly at Cauquenes (Figure 3A), indicating that water deficit had a greater impact in triticale compared to wheat. However, the difference in agronomic traits between the two species under WL conditions of Santa Rosa and Cauquenes indicated that triticale had higher GY, TKW, and KS than wheat, but lower SM2 (Figure 3B).

\section{Physiological Traits}

The $\Psi_{\mathrm{L}}$ and $\mathrm{E}$ at anthesis and grain filling were not significantly $(P>0.05)$ different between the two cereals, but triticale had on average a $23 \%$ higher An at anthesis and $24.7 \%$ lower gs than bread wheat (Table 2). The $\mathrm{G} \times \mathrm{E}$ interaction was only significant for gs and $\mathrm{Ci}$ at grain filling. The ratios of $\mathrm{An} / \mathrm{E}, \mathrm{An} / \mathrm{gs}$ at grain filling, and $\mathrm{An} / \mathrm{Ci}$ at anthesis and grain filling were superior in triticale (Table 2), particularly under WL conditions (Figure 3D). The environmental effect was highly significant $(P<0.001)$ for all traits and developing stages (Table 2); in 2016, An, gs, and E were severely reduced under WL conditions in both species (Figure 3C), but triticale had higher An and gs, and lower $\mathrm{Ci}$ at anthesis than wheat (Table 2). The exponential responses of An and gs to $\Psi_{\mathrm{L}}$ were similar in the two cereals (Figure 4), with no statistical differences between the slopes and the intercepts. As expected, positive relationships were found between An vs. gs, and An vs. E, indicating significant higher An and E values per unit of gs in triticale compared to wheat (Figure 5).

$\Delta^{13} \mathrm{C}$ in kernels was not significantly different between the two species but the $\mathrm{G} \times \mathrm{E}$ interaction was significant $(P<0.01)$ different (Table 1). The WL condition in Cauquenes, 2016 reduced $\Delta^{13} \mathrm{C}$ by 16 and $12 \%$ in triticale and wheat, respectively (Figure 3C).

Among the chlorophyll fluorescence parameters, triticale had significantly lower values of Fo at grain filling $(P<0.001)$ and $\mathrm{Fm}$ at anthesis $(P>0.05)$, but higher values of $\sim \mathrm{Fo}^{\prime}$ and $\mathrm{Fm}^{\prime}$ at anthesis $(P<0.05)$ (Table 3). The parameters for light-acclimated leaves, IK, ETRmax, and Y(II) were significant higher $(P<0.001)$ and $\mathrm{Y}(\mathrm{NPQ})$ was significantly lower $(P<0.05)$ in triticale at anthesis and grain filling (Figure 3D and Table 4). Under WL conditions in 2016, ETRmax was less effected in triticale, and also Y(NPQ) and NPQ increase more than in wheat, indicating better photochemical efficiency in triticale (Figure 3C).

$\mathrm{Y}(\mathrm{NO})$ and NPQ also differed between the two crops, being lower in triticale at grain filling and anthesis, respectively (Table 4). A significant environmental effect was observed for all chlorophyll fluorescence traits, except for Fm, however the $G \times E$ interaction was not significant (Tables 3, 4). The 
TABLE 1 | Above-ground biomass (AB; $\mathrm{g} \mathrm{m}^{-2}$ ), grain yield (GY; $\mathrm{g} \mathrm{m}^{-2}$ ), harvest index (HI), number of spikes per m2 (SM2), 1000 kernel weight (TKW; g), kernels per spike (KS), plant high $(\mathrm{PH})$, and carbon isotope discrimination $\left(\Delta^{13} \mathrm{C}\right)$ for triticale (Trit) cv. Aguacero and wheat (Wh) cv. Pandora, under well-watered (WW) and water-limited (WL) conditions at Santa Rosa (SR) (2014, 2015, and 2016) and Cauquenes (Cau) (2015 and 2016).

\begin{tabular}{|c|c|c|c|c|c|c|c|c|c|c|}
\hline Environment & Water regime & Specie & AB & GY & HI & SM2 & TKW & KS & PH & $\Delta^{13} \mathrm{C}$ \\
\hline \multirow[t]{2}{*}{ SR 2014} & WW & Trit & - & 1138 & - & 408 & - & - & 116 & - \\
\hline & & Wh & - & 956 & - & 497 & - & - & 89 & - \\
\hline \multirow[t]{4}{*}{ SR 2015} & WW & Trit & 2159 & 1008 & 0.46 & 312 & 56.66 & 57 & 118 & 19.10 \\
\hline & & Wh & 1493 & 733 & 0.49 & 345 & 45.43 & 47 & 89 & 19.04 \\
\hline & $W L$ & Trit & 2084 & 874 & 0.46 & 306 & 55.00 & 52 & 115 & 18.96 \\
\hline & & Wh & 1449 & 680 & 0.47 & 386 & 45.24 & 39 & 88 & 18.26 \\
\hline \multirow[t]{4}{*}{ CAU 2015} & WW & Trit & 2033 & 964 & 0.48 & 252 & 58.98 & 66 & 116 & 16.58 \\
\hline & & Wh & 2010 & 938 & 0.47 & 336 & 50.90 & 55 & 101 & 17.45 \\
\hline & $W L$ & Trit & 1872 & 835 & 0.45 & 271 & 43.62 & 72 & 124 & 16.61 \\
\hline & & Wh & 1745 & 736 & 0.42 & 370 & 44.10 & 45 & 104 & 17.28 \\
\hline \multirow[t]{4}{*}{ SR 2016} & WW & Trit & 2089 & 907 & 0.44 & 263 & 60.35 & 57 & 115 & 16.84 \\
\hline & & Wh & 1971 & 847 & 0.43 & 411 & 54.75 & 38 & 91 & 16.43 \\
\hline & $W L$ & Trit & 2364 & 974 & 0.41 & 332 & 52.77 & 56 & 116 & 16.24 \\
\hline & & Wh & 1671 & 694 & 0.42 & 377 & 46.49 & 40 & 90 & 16.55 \\
\hline \multirow[t]{4}{*}{ CAU 2016} & WW & Trit & 1678 & 598 & 0.36 & 240 & 60.19 & 41 & 109 & 15.69 \\
\hline & & Wh & 1293 & 430 & 0.33 & 286 & 47.94 & 31 & 90 & 15.50 \\
\hline & $W L$ & Trit & 1176 & 356 & 0.31 & 183 & 56.79 & 35 & 100 & 13.16 \\
\hline & & Wh & 1079 & 349 & 0.33 & 267 & 47.15 & 28 & 81 & 13.67 \\
\hline \multirow[t]{2}{*}{ Mean } & & Trit & 1932 & 850 & 0.42 & 286 & 55.54 & 54 & 114 & 16.65 \\
\hline & & Wh & 1589 & 707 & 0.42 & 364 & 47.75 & 40 & 91 & 16.77 \\
\hline \multirow[t]{3}{*}{ ANOVA } & G & & $* * *$ & $* * *$ & n.s. & $* * *$ & $* * *$ & $* * *$ & $* * *$ & n.s. \\
\hline & $E$ & & $* * *$ & $* * *$ & $* * *$ & $* * *$ & $* * *$ & $* * *$ & $* * *$ & $* * *$ \\
\hline & $G \times E$ & & n.s. & n.s. & n.s. & n.s. & $*$ & n.s. & n.s. & $* *$ \\
\hline
\end{tabular}

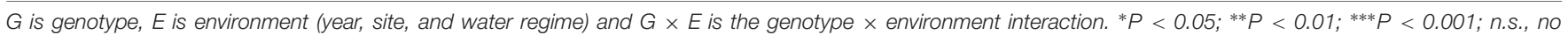
significant difference, $P>0.05$.

chlorophyll index and concentration were not different between the two crops, but the chlorophyll index and the Chl a:b ratio at grain filling was significantly higher in triticale $(P<0.001)$ (Tables 3, 5). During grain filling, the water-deficit reduced pigments and increased proline content in leaves (Table 5).

The evaluation of stomata morphology on the abaxial surface indicated that triticale had wider stomata, but lower stomatal density $(25.3 \%$ less) than wheat (Table 6). The length of the stomata showed no differences between cereals. Water-deficit in 2015 reduced the stomatal size in both species.

\section{Relationships Between Physiological and Agronomic Traits}

Correlation analysis between physiological traits (determined at anthesis and grain filling) and agronomic traits, showed a number of significant correlations, in both triticale and wheat (Table 7). GY was positively (and significant) correlated with $\mathrm{Ci}$ at anthesis and $\Delta^{13} \mathrm{C}$ in both species, as well as with gs at anthesis in triticale and fluorescence parameters $\left[\sim \mathrm{Fo}^{\prime}, \mathrm{Fm}^{\prime}\right.$, $\mathrm{Y}(\mathrm{NO})]$ at grain filling in wheat. In addition, GY was negatively correlated with An/gs at anthesis and NPQ at grain filling in both species, An/Ci at anthesis in triticale, and Y(NPQ) at grain filling in wheat. The TKW was positively correlated with An, gs, An/Ci, $\Psi_{\mathrm{L}}$, ETRmax, and $\mathrm{Y}(\mathrm{II})$ at grain filling in triticale, and with Chl and ETRmax in wheat. KS had a significant and positive correlation with $\mathrm{Ci}$, and a negative correlation with An/gs at anthesis, in both species; also significant correlations with some of the fluorescence parameters and $\Delta^{13} \mathrm{C}$ in wheat. In the case of HI the correlations were in general similar to those observed for GY.

The PCA revealed that the first two principal components (PC) explained 57.2\% of the observed variability (Supplementary Figure S1). There was a clear separation between years and species; the separation between both species was irrespective of the water regime. The clustering of the year 2016 was mainly based on physiological variables linked with plant water status $\left(\Psi_{L}\right)$, the net assimilation (An), efficiency in the use of water (An/gs, An/E), photochemical efficiency Y(II), IK, ETRmax, thermal dissipation of the photosynthetic apparatus [Y(NPQ) and NPQ] and chlorophyll content (Chl). In the other hand, the clustering of 2015 was mainly associated by productive variables such as GY, KPS, SM2, HI, AB, and $\mathrm{PH}$ (Supplementary Figure S1B).

\section{DISCUSSION}

\section{Yield and Its Agronomic Components}

The comparison between cereals in terms of traits associated with drought tolerance (Sinha et al., 1986; Lonbani and Arzani, 2011; Roohi et al., 2013; Kumar et al., 2014), source limitations 


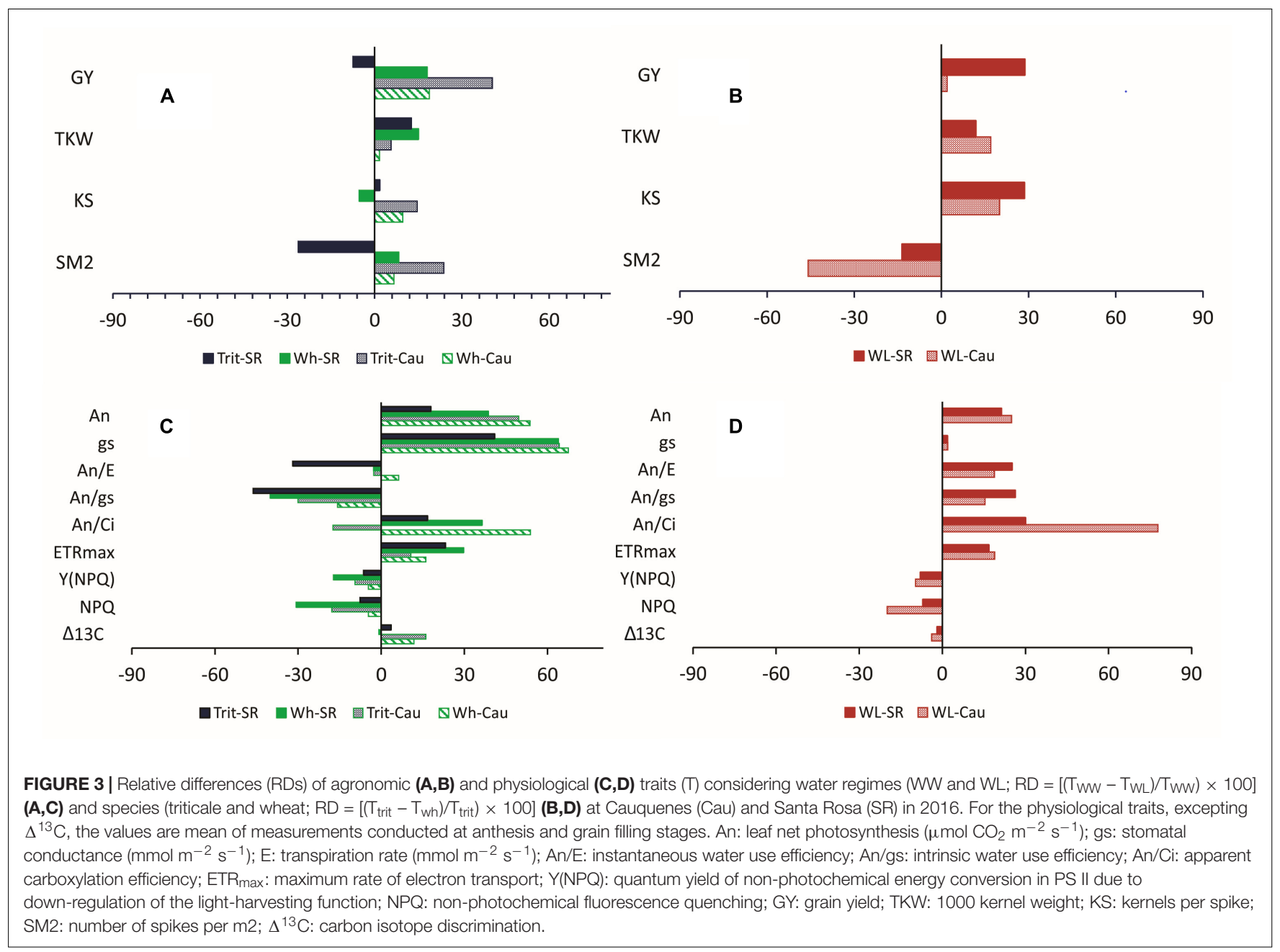

(Calderini et al., 2006; Motzo et al., 2013), yield potential (Ugarte et al., 2007; Villegas et al., 2010; Bassu et al., 2011; Estrada-Campuzano et al., 2012; Motzo et al., 2015), molecular markers and gene expression (Kavanagh et al., 2013; Latini et al., 2013), among others, contribute to understand the physiological basis of crop production. In our study, the comparison between the best spring cultivars of triticale and bread wheat indicated that triticale outyielded bread wheat in a wide range of environments (Figure 1). The regression coefficient (Finlay and Wilkinson slope) was significant $(P<0.01)$ larger in triticale $(1.15$ vs. 0.96 and 0.87 in wheat), indicating greater adaptability. The environmental index is a valuable tool for discriminating cultivars with augmented tolerance to drought stress (SioSe Mardeh et al., 2006), but also for genotypes of high yield potential in more favorable environments, like triticale in our study. The higher yield potential of triticale in high yielding environments has also been recorded in 16 sites in the United Kingdom, where the average GY of two triticale cultivars (8.27 and $\left.9.01 \mathrm{t} \mathrm{ha}^{-1}\right)$ was higher compared to two wheat cultivars (7.26 and $7.94 \mathrm{t} \mathrm{ha}^{-1}$ ) (Roques et al., 2017). Other studies comparing triticale and durum wheat in drought-prone Mediterranean environments (Australia, Spain, Sardinia, Lebanon, and Tunisia), also revealed the higher GY of triticale (Giunta et al., 1993; López-Castañeda and Richards, 1994; Villegas et al., 2010). However, in a subtropical climate like New Dehli, India, triticale did not outyield bread or durum wheat, with or without irrigation (Sinha et al., 1986).

Agronomic components help to understand the variations in GY associated with genetic improvement, crop management or environmental factors in cereals (Giunta et al., 1993; del Pozo et al., 2012, 2014, 2016). In this study, the higher GY of triticale is explained by greater TKW and KS values (Table 1). Also, the higher $\mathrm{KS}$ in triticale was able to compensate for the lower number of spikes per $\mathrm{m}^{2}$, compared to wheat. The number of grains per unit area is the major component that determines yield in cereals (Peltonen-Sainio et al., 2007; Slafer et al., 2014) and in the case of triticale and wheat, the average number of grains per $\mathrm{m}^{2}$ were similar $(14,943$ and 14,256 grain $\mathrm{m}^{-2}$, respectively). However, the relationship between GY and the number of grains per $\mathrm{m}^{2}$ (Figure 2) indicates that the greater TKW of triticale explained the differences in GY between the two cereals. Indeed, spike size 


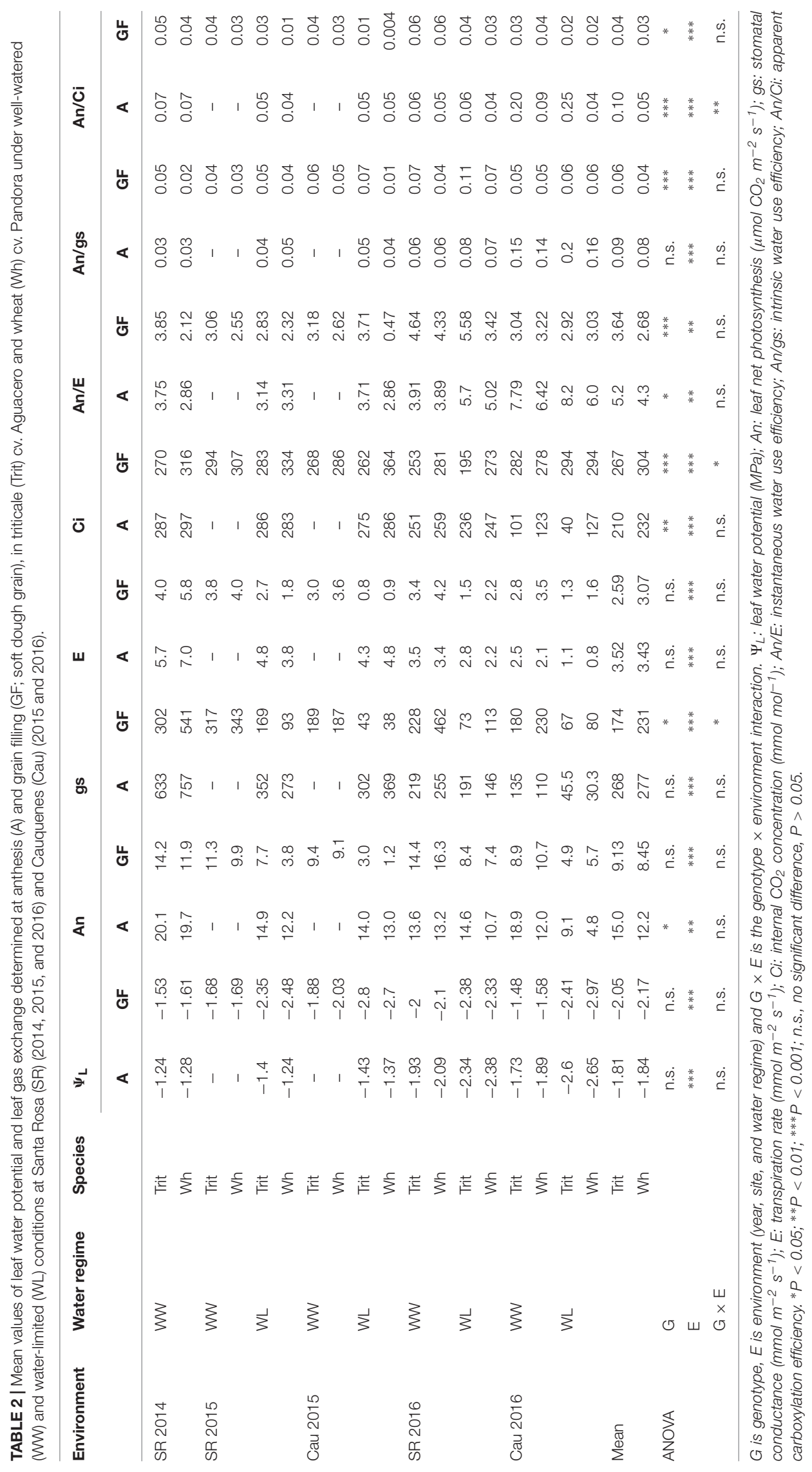



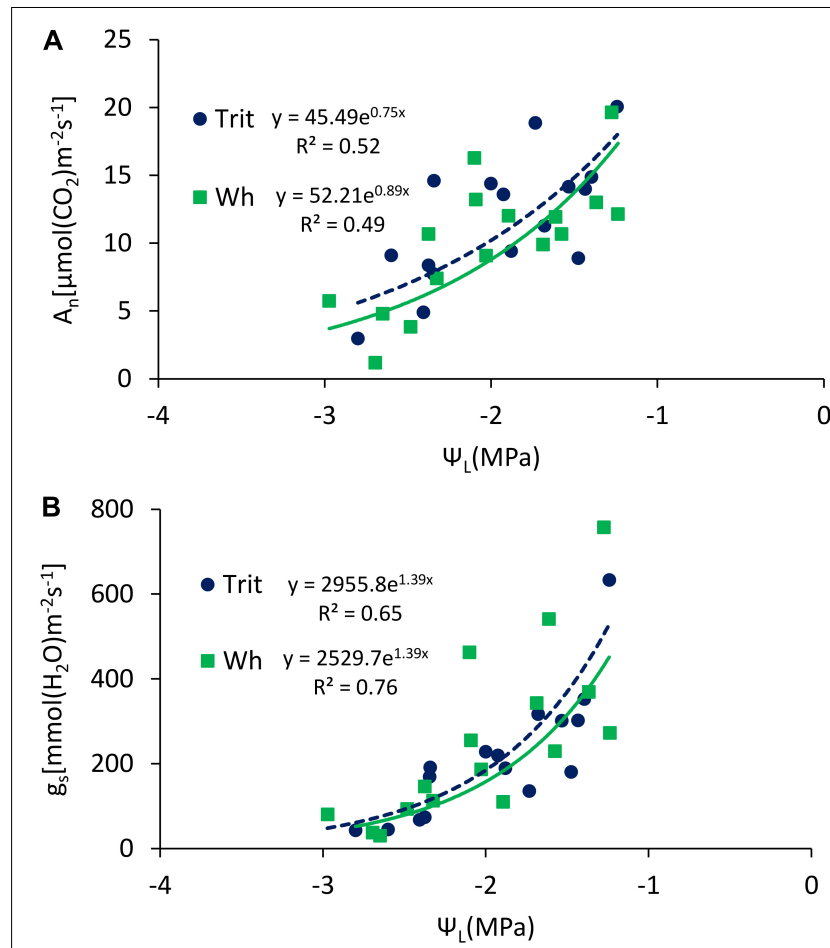

FIGURE 4 | Relationships between leaf water potential $\left(\Psi_{L}\right)$ and $(\mathbf{A})$ maximum net photosynthesis $\left(A_{n}\right)$, and $(\mathbf{B})$ stomatal conductance $\left(g_{s}\right)$, determined at anthesis and grain filling of triticale and wheat grown under well-watered (WW) and water-limited (WL) conditions, at Cauquenes and Santa Rosa in 2014, 2015, and 2016. The comparison of the regression lines indicated not significant difference between the slopes $(P=0.34 ; 0.36$ for $\mathbf{A}, \mathbf{B})$, or the intercepts $(P=0.57 ; 0.85$ for $\mathbf{A}, \mathbf{B})$.

and fertility have been demonstrated to contribute more than tillering capacity to the number of grains set per $\mathrm{m}^{2}$ (Motzo et al., 2015). In other cases, an increase in the proportion of grains in distal positions (Ferrante et al., 2017) increases the final yield. Finally, HI was similar in both species but, under more severe stress (2016) wheat tended to present higher HI than triticale.

In areas with Mediterranean climates, the grain filling stage of cereals generally occurs under conditions of water scarcity (Dolferus et al., 2013; Sanchez-Bragado et al., 2014), and the effect of precipitation or water availability influences GY via fluctuations in the amount and frequency (Sinha et al., 1986), but the relative impact varies with the intensity of stress and the plant species (Pinheiro et al., 2011). In our study, rainfalls occurred during grain filling (in October-November) in 2015 led to exceptionally high GY $\left(>800 \mathrm{~g} \mathrm{~m}^{-2}\right)$ at Cauquenes, and actually no differences were detected between WW and WL (rainfed) conditions in that year (Table 1). However, in 2016 the water deficit was more severe, particularly at Cauquenes, and this lead to a reduction in GY and its components, in both species.

In this study, the $\mathrm{PH}$ of triticale was an overage 25\% higher than wheat (Table 1), which agree with other studies (Khan et al., 2015; Motzo et al., 2015; Roques et al., 2017). Indeed, the higher $\mathrm{PH}$ of triticale can improve crop competitiveness
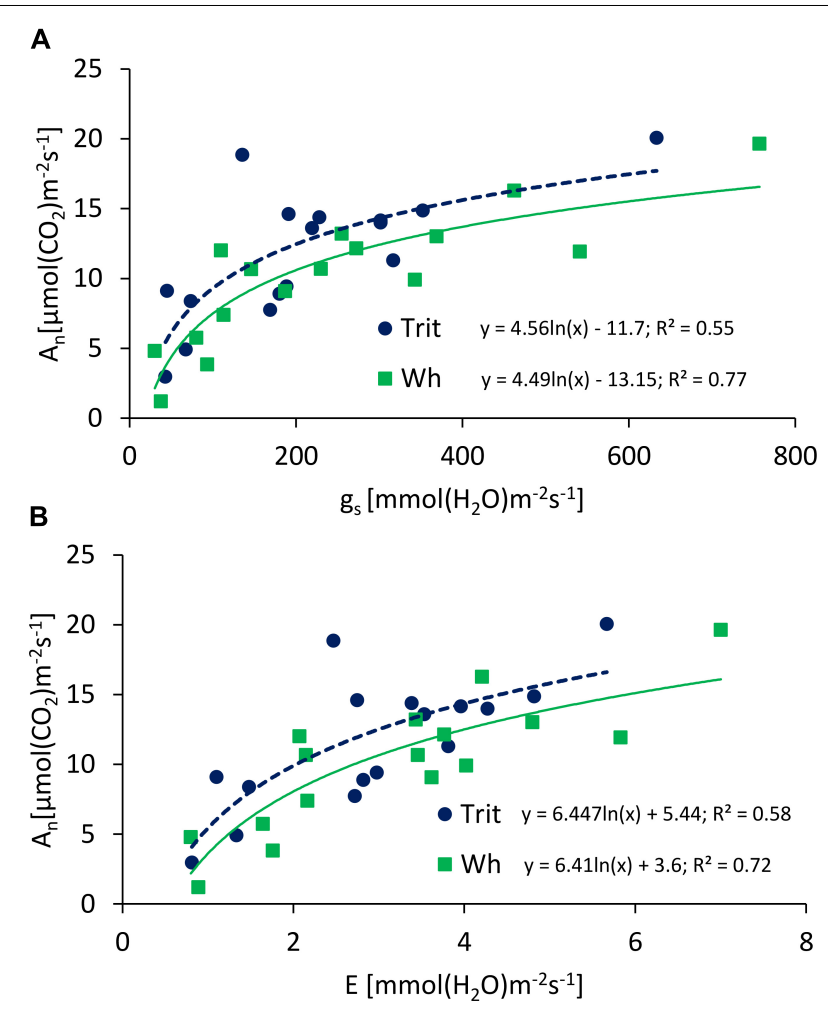

FIGURE $\mathbf{5}$ | Relationships between maximum net photosynthesis $\left(A_{n}\right)$ and $(\mathbf{A})$ stomatal conductance to $\mathrm{CO}_{2}\left(\mathrm{~g}_{\mathrm{s}}\right)$ and $(\mathbf{B})$ transpiration $(\mathrm{E})$, determined at anthesis and grain filling of triticale and wheat grown under well-watered (WW) and water-limited (WL) conditions, at Cauquenes and Santa Rosa in 2014, 2015, and 2016. The comparison of the regression lines indicated significant difference between the slopes $(P=0.01 ; 0.002$ for $\mathbf{A}, \mathbf{B})$, but not significant difference between intercepts $(P=0.47 ; 0.26$ for $\mathbf{A}, \mathbf{B})$.

(Beres et al., 2010), which is consistent with its higher GY and biomass. In addition, higher $\mathrm{PH}$ and biomass probably imply greater amount of water-soluble carbohydrate that can be mobilized to the grain, especially under water-limited conditions (Xue et al., 2009).

\section{Physiological Traits}

The assimilates necessary for filling the grain are provided by photosynthesis in the leaves (Evans et al., 1975) and spikes (Tambussi et al., 2007; Maydup et al., 2012), and the redistribution of reserves stored in vegetative tissues during the pre- and/or post-anthesis periods, which are translocated to the growing grains (Schnyder, 1993; Zhang et al., 2006). Triticale had higher leaf net photosynthesis than bread wheat, in all the environments and water conditions tested in our study, which could explain the higher biomass of this species. Moreover, the fact that triticale had higher photosynthetic rates during the grain filling period, especially in the initial stages of grain filling, reveals that the contribution of $\mathrm{C}$ assimilated during this stage to grain filling was higher than in wheat. Such a trait also contributed to the increased GY of triticale, through the production of reserve carbohydrates, which are 
TABLE 3 | Mean values of chlorophyll index and chlorophyll fluorescence parameters determined at anthesis (A) and grain filling (GF; soft dough grain) in triticale (Trit) cV. Aguacero and wheat (Wh) cv. Pandora under well-watered (WW) and water-limited (WL) conditions at Santa Rosa (SR) (2014, 2015, and 2016) and Cauquenes (Cau) (2015 and 2016).

\begin{tabular}{|c|c|c|c|c|c|c|c|c|c|c|c|c|c|c|}
\hline \multirow[t]{2}{*}{ Environment } & \multirow[t]{2}{*}{ Water regime } & \multirow[t]{2}{*}{ Species } & \multicolumn{2}{|c|}{ Chl index } & \multicolumn{2}{|c|}{ Fo } & \multicolumn{2}{|c|}{ Fm } & \multicolumn{2}{|c|}{ Fv/Fm } & \multicolumn{2}{|c|}{$\sim \mathbf{F o}^{\prime}$} & \multicolumn{2}{|c|}{$\mathbf{F m}^{\prime}$} \\
\hline & & & A & GF & A & GF & A & GF & A & GF & $\mathbf{A}$ & GF & A & GF \\
\hline \multirow[t]{2}{*}{ SR 2014} & WW & Trit & 47.76 & 44.62 & 1.64 & 1.68 & 6.47 & 6.56 & 0.75 & 0.74 & 1.3 & 1.43 & 2.63 & 2.87 \\
\hline & & Wh & 43.54 & 32.34 & 1.61 & 1.79 & 6.46 & 6.32 & 0.75 & 0.71 & 1.22 & 1.49 & 2.66 & 3.03 \\
\hline \multirow[t]{4}{*}{ SR 2015} & WW & Trit & - & 33.40 & - & 1.36 & - & 5.99 & - & 0.71 & - & 1.25 & - & 2.62 \\
\hline & & Wh & - & 25.58 & - & 1.55 & - & 6.66 & - & 0.77 & - & 1.32 & - & 2.72 \\
\hline & WL & Trit & 44.14 & 32.89 & 1.5 & 1.34 & 6.29 & 6.02 & 0.7 & 0.71 & 1.38 & 1.18 & 2.92 & 2.39 \\
\hline & & Wh & 40.85 & 29.85 & 1.61 & 1.52 & 6.82 & 6.27 & 0.76 & 0.75 & 1.22 & 1.19 & 2.61 & 2.41 \\
\hline \multirow[t]{4}{*}{ Cau 2015} & WW & Trit & - & 50.32 & - & 1.49 & - & 6.19 & - & 0.7 & - & 3.01 & - & 1.37 \\
\hline & & Wh & - & 38.73 & - & 1.68 & - & 6.87 & - & 0.76 & - & 3.29 & - & 1.41 \\
\hline & WL & Trit & 52.54 & 45.91 & 1.54 & 1.45 & 6.82 & 6.26 & 0.77 & 0.7 & 1.38 & 1.36 & 3.14 & 3 \\
\hline & & Wh & 42.14 & 33.67 & 1.59 & 1.68 & 6.85 & 6.85 & 0.77 & 0.75 & 1.31 & 1.27 & 2.95 & 2.5 \\
\hline \multirow[t]{4}{*}{ SR 2016} & WW & Trit & 59.06 & 53.88 & 1.37 & 1.33 & 6.21 & 6.02 & 0.78 & 0.79 & 1.2 & 1.1 & 2.6 & 2.33 \\
\hline & & Wh & 52.20 & 46.41 & 1.35 & 1.39 & 6.67 & 6.52 & 0.8 & 0.79 & 1.16 & 1.21 & 2.69 & 2.93 \\
\hline & WL & Trit & 58.00 & 46.12 & 1.38 & 1.35 & 6.63 & 5.88 & 0.79 & 0.77 & 1.2 & 1.09 & 2.79 & 2.09 \\
\hline & & Wh & 51.19 & 38.58 & 1.38 & 1.45 & 6.65 & 6.06 & 0.79 & 0.76 & 1.2 & 1.13 & 2.55 & 2.17 \\
\hline \multirow[t]{4}{*}{ Cau 2016} & WW & Trit & 49.98 & 54.34 & 1.52 & 1.51 & 6.85 & 6.57 & 0.78 & 0.77 & 1.33 & 1.25 & 2.78 & 2.61 \\
\hline & & Wh & 43.35 & 42.64 & 1.5 & 1.55 & 6.86 & 6.67 & 0.78 & 0.77 & 1.12 & 1.2 & 2.24 & 2.3 \\
\hline & $W L$ & Trit & 47.66 & 44.58 & 1.55 & 1.45 & 6.64 & 6.63 & 0.77 & 0.78 & 1.29 & 1.14 & 2.69 & 2.15 \\
\hline & & Wh & 42.53 & 37.18 & 1.54 & 1.46 & 6.86 & 6.67 & 0.78 & 0.78 & 1.14 & 1.1 & 2.35 & 2.02 \\
\hline \multirow[t]{2}{*}{ Mean } & & Trit & 51.31 & 45.12 & 1.5 & 1.44 & 6.56 & 6.24 & 0.76 & 0.74 & 1.3 & 1.24 & 2.79 & 2.56 \\
\hline & & Wh & 45.12 & 36.11 & 1.51 & 1.56 & 6.74 & 6.54 & 0.78 & 0.76 & 1.2 & 1.26 & 2.58 & 2.6 \\
\hline \multirow[t]{3}{*}{ ANOVA } & $\mathrm{G}$ & & $* *$ & $* * *$ & n.s. & $* * *$ & n.s. & n.s. & n.s. & n.s. & $* *$ & n.s. & $*$ & n.s. \\
\hline & $E$ & & $* *$ & $* * *$ & $* * *$ & $* * *$ & n.s. & n.s. & $*$ & n.s. & $*$ & $* * *$ & $*$ & $* * *$ \\
\hline & $G \times E$ & & n.s. & n.s. & n.s. & n.s. & n.s. & n.s. & n.s. & n.s. & n.s. & n.s. & n.s. & $*$ \\
\hline
\end{tabular}

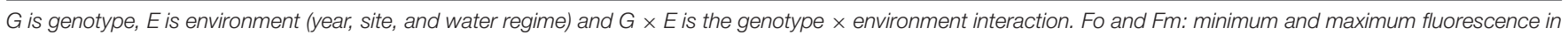

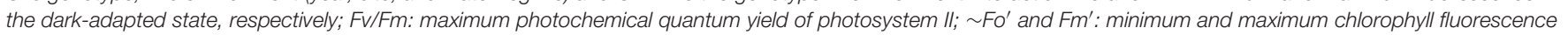
yield, respectively, when the photosystem II reaction centers were in the open state. ${ }^{*} P<0.05 ; * * P<0.01 ;{ }^{* * *} P<0.001 ;$ n.s., no significant difference, $P>0.05$.

stored in the stem and then mobilized to the grain (Méndez et al., 2011; del Pozo et al., 2012; Stella et al., 2016; Yáñez et al., 2017). On the other hand, our study showed that drought stress impaired photosynthesis and the production of photosynthetic assimilates that are directly transferred to the grain (Schnyder, 1993), as observed in Cauquenes in 2016 where An and GY were severely reduced under WL conditions, but triticale maintained higher rates of phosynthesis at anthesis than wheat (Table 2).

Stomatal opening proved to be a target factor involved in the different photosynthetic performance of triticale and bread wheat plants. Stomata control the balance of gases between the internal leaf environment and the external atmosphere (McAusland et al., 2016) regulating $\mathrm{CO}_{2}$ uptake for photosynthesis and transpiration and thus determining plant productivity (Lawson and Blatt, 2014). In addition, the stomatal size and density vary greatly between plant species (Giday et al., 2013) and are influenced by the growing environment (Hetherington and Woodward, 2003; Franks and Beerling, 2009). This was evident in the present study, where a mild water stress at Santa Rosa in 2015 generated a significant reduction in stomatal width and length in both cereals (Table 6).
Leaves with smaller stomata and greater stomatal density respond quickly to changes in water availability (Drake et al., 2013; Giday et al., 2013; Raven, 2014; Buckley, 2017). In fact, negative correlations between stomatal density and size were reported for wheat (Shahinnia et al., 2016; Hughes et al., 2017). In our study, triticale had lower stomatal density (25.3\%) and higher response of gs to water availability compared to bread wheat, especially during grain filling, thus increasing the efficiency of water use in leaves (Franks et al., 2015). In fact, $\mathrm{An} / \mathrm{E}$ and $\mathrm{An} / \mathrm{gs}$ were higher in triticale compared to wheat (35.8 and 50\% respectively, in grain filling) (Table 2), particularly under WL conditions in 2016 (Figure 3C), indicating that for a similar loss of water the amount of photosynthesis was higher in triticale (Figure 5). Also, the apparent carboxylation efficiency $(\mathrm{An} / \mathrm{Ci})$ was less affected by WL conditions in triticale (Figure 3C), suggesting greater intrinsic photosynthetic capacity than wheat (Monneveux et al., 2006).

Abiotic stress has adverse effects on the whole plant and on its metabolites, but chloroplasts and proteins are substantially affected by stress factors (Huseynova et al., 2016). Under water-limited conditions the leaf water potential decreased and proline content increased, without significant 


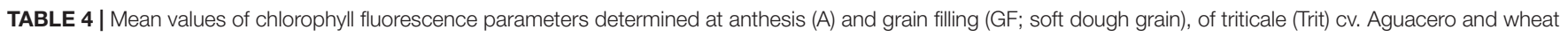
(Wh) cv. Pandora under well-watered (WW) and water-limited (WL) conditions at Santa Rosa (SR) (2014, 2015, and 2016) and Cauquenes (Cau) (2015 and 2016).

\begin{tabular}{|c|c|c|c|c|c|c|c|c|c|c|c|c|c|c|c|c|}
\hline \multirow[t]{2}{*}{ Environment } & \multirow{2}{*}{$\begin{array}{l}\text { Water } \\
\text { regime }\end{array}$} & \multirow[t]{2}{*}{ Species } & \multicolumn{2}{|c|}{ Alpha } & \multicolumn{2}{|c|}{ IK } & \multicolumn{2}{|c|}{ ETRmax } & \multicolumn{2}{|c|}{$Y(I I)$} & \multicolumn{2}{|c|}{$\mathrm{Y}(\mathrm{NPQ})$} & \multicolumn{2}{|c|}{$\mathrm{Y}(\mathrm{NO})$} & \multicolumn{2}{|c|}{ NPQ } \\
\hline & & & A & GF & A & GF & $\mathbf{A}$ & GF & A & GF & A & GF & A & GF & A & GF \\
\hline \multirow[t]{2}{*}{ SR 2014} & WW & Trit & 0.32 & 0.34 & 309.7 & 274.0 & 98.2 & 88.1 & 0.16 & 0.15 & 0.50 & 0.48 & 0.34 & 0.37 & 0.37 & 1.31 \\
\hline & & Wh & 0.32 & 0.34 & 351.7 & 189.5 & 111.2 & 64.7 & 0.17 & 0.11 & 0.49 & 0.46 & 0.34 & 0.43 & 0.37 & 1.12 \\
\hline \multirow[t]{4}{*}{ SR 2015} & WW & Trit & - & 0.31 & - & 331.9 & - & 101.6 & - & 0.16 & - & 0.45 & - & 0.32 & - & 1.35 \\
\hline & & Wh & - & 0.33 & - & 231.9 & - & 75.1 & - & 0.12 & - & 0.52 & - & 0.36 & - & 1.51 \\
\hline & $W L$ & Trit & 0.30 & 0.35 & 333.4 & 202.0 & 97.7 & 68.6 & 0.16 & 0.12 & 0.45 & 0.52 & 0.32 & 0.29 & 1.29 & 1.66 \\
\hline & & Wh & 0.31 & 0.34 & 285.7 & 196.6 & 86.7 & 66.7 & 0.15 & 0.10 & 0.53 & 0.56 & 0.33 & 0.34 & 1.73 & 1.66 \\
\hline \multirow[t]{4}{*}{ Cau 2015} & WW & Trit & - & 0.32 & - & 337.9 & - & 105.6 & - & 0.17 & - & 0.42 & - & 0.34 & - & 1.15 \\
\hline & & Wh & - & 0.33 & - & 284.0 & - & 92.3 & - & 0.14 & - & 0.45 & - & 0.41 & - & 1.12 \\
\hline & $W L$ & Trit & 0.30 & 0.33 & 453.1 & 240.6 & 132.7 & 78.1 & 0.20 & 0.12 & 0.43 & 0.45 & 0.37 & 0.35 & 1.23 & 1.26 \\
\hline & & Wh & 0.29 & 0.35 & 372.0 & 165.2 & 105.1 & 57.6 & 0.17 & 0.09 & 0.48 & 0.58 & 0.36 & 0.33 & 1.42 & 1.85 \\
\hline \multirow[t]{4}{*}{ SR 2016} & WW & Trit & 0.31 & 0.32 & 479.8 & 399.3 & 147.0 & 132.9 & 0.22 & 0.20 & 0.46 & 0.49 & 0.33 & 0.31 & 1.42 & 1.62 \\
\hline & & $W h$ & 0.31 & 0.32 & 424.0 & 372.6 & 131.0 & 123.5 & 0.19 & 0.18 & 0.48 & 0.45 & 0.33 & 0.37 & 1.51 & 1.17 \\
\hline & $W L$ & Trit & 0.33 & 0.32 & 401.2 & 267.2 & 130.5 & 84.5 & 0.19 & 0.14 & 0.46 & 0.55 & 0.34 & 0.31 & 1.42 & 1.85 \\
\hline & & Wh & 0.31 & 0.30 & 357.3 & 238.8 & 109.8 & 69.1 & 0.17 & 0.11 & 0.52 & 0.57 & 0.32 & 0.32 & 1.65 & 1.85 \\
\hline \multirow[t]{4}{*}{ Cau 2016} & WW & Trit & 0.31 & 0.31 & 395.2 & 468.8 & 119.7 & 141.3 & 0.19 & 0.22 & 0.48 & 0.47 & 0.33 & 0.31 & 1.50 & 1.53 \\
\hline & & Wh & 0.29 & 0.31 & 395.9 & 368.1 & 116.1 & 109.4 & 0.19 & 0.18 & 0.55 & 0.54 & 0.26 & 0.28 & 2.16 & 1.93 \\
\hline & $W L$ & Trit & 0.30 & 0.31 & 422.2 & 351.3 & 125.4 & 107.8 & 0.20 & 0.17 & 0.48 & 0.56 & 0.32 & 0.27 & 1.48 & 2.09 \\
\hline & & Wh & 0.29 & 0.33 & 336.7 & 274.7 & 99.4 & 89.8 & 0.16 & 0.15 & 0.55 & 0.59 & 0.29 & 0.26 & 1.96 & 2.32 \\
\hline \multirow[t]{2}{*}{ Mean } & & Trit & 0.31 & 0.32 & 399.2 & 319.2 & 121.6 & 100.9 & 0.19 & 0.16 & 0.46 & 0.49 & 0.34 & 0.32 & 1.24 & 1.54 \\
\hline & & Wh & 0.30 & 0.33 & 360.5 & 257.9 & 108.4 & 83.1 & 0.17 & 0.13 & 0.51 & 0.52 & 0.32 & 0.35 & 1.54 & 1.61 \\
\hline \multirow[t]{3}{*}{ ANOVA } & $G$ & & n.s. & n.s. & $*$ & $* * *$ & $* *$ & $* * *$ & $* *$ & $* * *$ & $* * *$ & $*$ & n.s. & $*$ & $* * *$ & n.s. \\
\hline & $E$ & & $*$ & * & $* * *$ & $* * *$ & $* * *$ & $* * *$ & $* *$ & $* * *$ & n.s. & $* * *$ & n.s. & $* * *$ & $* * *$ & $* * *$ \\
\hline & $G \times E$ & & n.s. & n.s. & n.s. & n.s. & n.s. & n.s. & n.s. & n.s. & n.s. & n.s. & n.s. & n.s. & n.s. & n.s. \\
\hline
\end{tabular}

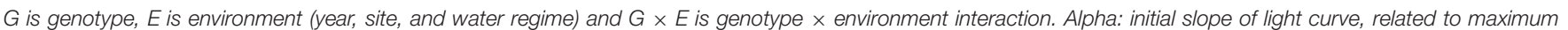

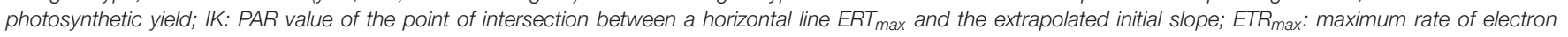

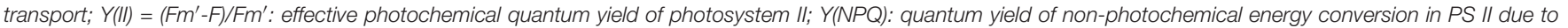

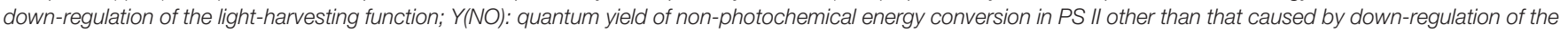
light-harvesting function; NPQ, non-photochemical fluorescence quenching. ${ }^{*} P<0.05 ; * *<0.01 ; * * * P<0.001 ;$ n.s., no significant difference, $P>0.05$.

TABLE 5 | Mean values of chlorophyll index, pigments ( $\left.\mathrm{mg} \mathrm{gFW}^{-1}\right)$ and proline $\left(\mathrm{mg} \mathrm{gFW}^{-1}\right)$ determined at anthesis (A) and grain filling (GF; soft dough grain), of triticale (Trit) cv. Aguacero and wheat (Wh) cv. Pandora under well-watered (WW) and water-limited (WL) conditions at Santa Rosa (2014 and 2015) and Cauquenes (2015).

\begin{tabular}{|c|c|c|c|c|c|c|c|c|c|c|c|c|}
\hline \multirow[t]{2}{*}{ Environment } & \multirow[t]{2}{*}{ Water regime } & \multirow[t]{2}{*}{ Species } & \multicolumn{2}{|l|}{ Chl a } & \multicolumn{2}{|l|}{ Chl b } & \multicolumn{2}{|l|}{ Chl a:b } & \multicolumn{2}{|l|}{ Chl T } & \multicolumn{2}{|l|}{ Proline } \\
\hline & & & A & GF & A & GF & A & GF & A & GF & A & GF \\
\hline \multirow[t]{2}{*}{ SR 2014} & WW & Trit & 1.68 & 1.94 & 0.98 & 1.16 & 1.71 & 1.67 & 2.93 & 3.42 & 0.3 & 0.29 \\
\hline & & Wh & 1.83 & 1.67 & 1.09 & 1.03 & 1.72 & 1.63 & 3.28 & 1.09 & 0.24 & 0.26 \\
\hline \multirow[t]{4}{*}{ SR 2015} & WW & Trit & - & 1.17 & - & 0.91 & - & 1.29 & - & 2.1 & - & 0.46 \\
\hline & & Wh & - & 0.95 & - & 0.76 & - & 1.23 & - & 2.97 & - & 0.33 \\
\hline & $W L$ & Trit & 1.68 & 0.86 & 1.3 & 0.68 & 1.29 & 1.28 & 2.99 & 1.54 & 0.19 & 0.65 \\
\hline & & Wh & 1.88 & 0.60 & 1.41 & 0.50 & 1.29 & 1.19 & 3.26 & 1.71 & 0.63 & 0.81 \\
\hline \multirow[t]{4}{*}{ CAU 2015} & WW & Trit & - & 1.69 & - & 1.28 & - & 1.33 & - & 2.99 & - & 0.98 \\
\hline & & Wh & - & 1.91 & - & 1.46 & - & 1.31 & - & 3.38 & - & 0.59 \\
\hline & $W L$ & Trit & 1.90 & 1.30 & 1.46 & 1.00 & 1.31 & 1.30 & 3.38 & 2.31 & 0.29 & 2.67 \\
\hline & & Wh & 1.76 & 1.02 & 1.37 & 0.83 & 1.29 & 1.22 & 3.15 & 1.86 & 0.20 & 2.51 \\
\hline \multirow[t]{2}{*}{ Mean } & & Trit & 1.75 & 1.39 & 1.25 & 1.01 & 1.44 & 1.37 & 3.10 & 2.47 & 0.26 & 1.01 \\
\hline & & Wh & 1.83 & 1.23 & 1.29 & 0.91 & 1.43 & 1.31 & 3.23 & 2.20 & 0.36 & 0.9 \\
\hline \multirow[t]{3}{*}{ ANOVA } & & $\mathrm{G}$ & n.s. & n.s. & n.s. & n.s. & n.s. & $* * *$ & n.s. & n.s. & n.s. & n.s. \\
\hline & & E & n.s. & $* * *$ & $* *$ & $* * *$ & $* * *$ & $* * *$ & n.s. & $* * *$ & n.s. & $* *$ \\
\hline & & $G \times E$ & n.s. & n.s. & n.s. & n.s. & n.s. & n.s. & n.s. & n.s. & n.s. & n.s. \\
\hline
\end{tabular}

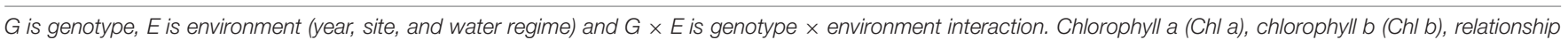
between chlorophyll a and b (Chl a:b), total chlorophyll (Chl T) and proline. ${ }^{*} P<0.05$; ${ }^{* *} P<0.01$; ${ }^{* * *} P<0.001 ;$ n.s., no significant difference, $P>0.05$. 
TABLE 6 | Stomatal width $\left(S_{W}\right)$, stomatal length $\left(S_{L}\right)$, and stomatal density (ED, number of stomata per square millimeter) at grain filling in triticale cV. Aguacero and bread wheat cV. Pandora, at Santa Rosa under well-watered (WW) conditions in 2014 and under WW and water-limited (WL) conditions in 2015.

\begin{tabular}{|c|c|c|c|c|c|}
\hline Year & Water regime & Species & $\mathrm{S}_{\mathrm{W}}(\mathrm{mm})$ & $\mathrm{S}_{\mathrm{L}}(\mathrm{mm})$ & $\mathrm{ED}\left(\mathrm{mm}^{2}\right)$ \\
\hline \multirow[t]{2}{*}{2014} & WW & Tri & 26.08 & 50.36 & 49.78 \\
\hline & & Wh & 24.80 & 50.50 & 62.95 \\
\hline \multirow[t]{4}{*}{2015} & WW & Tri & 33.86 & 54.81 & 47.64 \\
\hline & & Wh & 29.22 & 52.04 & 66.32 \\
\hline & WL & Tri & 26.14 & 48.39 & 46.63 \\
\hline & & Wh & 25.33 & 48.00 & 63.65 \\
\hline \multirow[t]{2}{*}{ Mean } & & Tri & 28.69 & 51.19 & 48.02 \\
\hline & & Wh & 26.45 & 50.18 & 64.31 \\
\hline \multirow[t]{3}{*}{ ANOVA } & & $G$ & $* * *$ & n.s. & $* * *$ \\
\hline & & $E$ & $* * *$ & $* * *$ & n.s. \\
\hline & & $G \times E$ & $* * *$ & n.s. & n.s \\
\hline
\end{tabular}

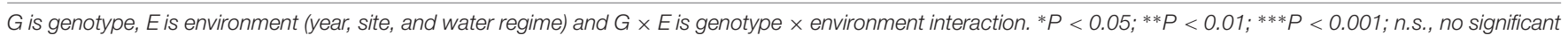
difference, $P>0.05$.

$(P<0.05)$ differences between the cereals. The larger availability of free proline in drought-affected plants was associated with its role as an osmoregulant that contributes to overcoming leaf dehydration by maintaining negative water potential to avoid water loss (Ramanjulu and Bartels, 2002). In this study, proline content increased during grain filling in both species, associated to the decline in $\Psi_{\mathrm{L}}$ (Tables 2, 5).

Also, at the grain filling stage triticale presented a higher Chl index and chl a:b (29.4 and 4.6\%, respectively) than wheat. It has been reported that the slow senescence of the leaf canopy (chlorophyll retention) after flowering helps to maintain the process of grain filling (Gous et al., 2013; Kholová et al., 2014). Therefore, triticale seems to maintain higher chlorophyll content and rates of photosynthesis during grain filling than wheat, indicating that triticale has a functional stay-green mechanism (Borrell et al., 2000), which could be related to the larger grain size.

Matching light capture and energy demand is especially relevant for plants subjected to stressful growth conditions (Lawlor and Tezara, 2009). The fact that photosynthesis is a major energy demanding process implies that in cases where photosynthesis is impaired and light excitation energy is in excess, leaves might suffer photooxidative damage. The excessive excitation energy in photosystem II (PSII) will lead to an impairment of photosynthetic function, progress to an accumulation of reactive oxygen species (ROS), and thereby result in oxidative stress. Changes in chlorophyll fluorescence parameters for dark-adapted leaves are expected under severe drought or heat stress, such as increases in Fo and decreases in Fm and Fv/Fm (Roostaei et al., 2011). In contrast, the value of $\mathrm{Fv} / \mathrm{Fm}$ for non-stressed leaves is remarkably consistent at $\sim 0.75$ (Björkman and Demmig, 1987). In our experiment Fm and Fv/Fm were not different between the two cereals and among environments, except at anthesis for Fv/Fm (Table 3), and this was probably because the plants were not exposed to severe water stress. The higher ETRmax of triticale compared to wheat (12.2 and $21.4 \%$ at anthesis and grain filling, respectively) and Y(II)
(11.8 and $23.1 \%$ at anthesis and grain filling, respectively) is consistent with the higher An observed at anthesis (Tables 2, 4). Y(II) corresponds to the fraction of energy that is photochemically converted in PSII (Klughammer and Schreiber, 2008; Scherner et al., 2013), therefore triticale shows a better PSII capacity (Sharma et al., 2015). However, triticale had a lower NPQ compared to wheat (19.5\%), indicating that wheat may be able to better regulate nonphotochemical energy dissipation (Sofo, 2011), at the expense of photosynthesis.

\section{Relationships Between Physiological and Agronomic Traits}

$\Delta^{13} \mathrm{C}$ was positively correlated with $\mathrm{GY}$ and $\mathrm{HI}$, but the correlation was higher with HI (Table 7), and this could reflect the efficiency of carbon partitioning to the kernel (Merah et al., 2001). During grain growth, most of the assimilated come from photosynthesis in post-anthesis (Munjonji et al., 2017); in the case of triticale, the higher An, associated to greater light capture (higher biomass) and grains/ear may be driving the higher yields (Roques et al., 2017).

According to Motzo et al. (2013), the yield potential of triticale was associated to greater stomatal conductance, nevertheless in the present research wheat presented higher gs, but also used more energy in photoprotection [Y(NPQ) and NPQ] than triticale (Figure 4 and Table 4); this could explain, at least in part, the lower GY of wheat, particularly under water-limited conditions. The PCA indicates that in more stressful situations, the differences between species were mainly determined by physiological traits (and TKW), especially the functioning of the photosynthetic apparatus, whereas in less stressful conditions, with fewer limitations for the assimilation of $\mathrm{CO}_{2}$, the differences between species are determined for its productivity.

Thousand kernel weight presents in general high heritability and is less affected by the water deficit (Arguello et al., 2016; Mathew et al., 2018). In triticale, the significant correlation between TKW and gas exchange (An, gs, An/Ci), and the higher chlorophyll content compared to wheat, suggest that triticale 
TABLE 7 | Correlation matrix between agronomic and physiological traits determined at anthesis (A) and grain filling (GF), in triticale and wheat.

\begin{tabular}{|c|c|c|c|c|c|c|c|c|c|}
\hline \multirow[t]{2}{*}{ Trait } & \multirow{2}{*}{$\begin{array}{l}\text { Phenological } \\
\text { Stage }\end{array}$} & \multicolumn{4}{|c|}{ Triticale } & \multicolumn{4}{|c|}{ Wheat } \\
\hline & & GY & TKW & KS & $\mathrm{HI}$ & GY & TKW & KS & $\mathrm{HI}$ \\
\hline \multirow[t]{2}{*}{ An } & $A$ & 0.12 & 0.21 & 0.06 & 0.16 & 0.08 & 0.14 & 0.33 & 0.18 \\
\hline & GF & 0.27 & 0.63 & 0.04 & 0.24 & 0.27 & 0.36 & -0.35 & 0.03 \\
\hline \multirow[t]{2}{*}{ gs } & A & 0.50 & -0.27 & 0.35 & 0.75 & 0.18 & -0.01 & 0.59 & 0.44 \\
\hline & GF & 0.32 & 0.40 & 0.06 & 0.31 & 0.37 & 0.27 & -0.15 & 0.16 \\
\hline \multirow[t]{2}{*}{$\mathrm{Ci}$} & A & 0.71 & -0.31 & 0.56 & 0.89 & 0.56 & -0.10 & 0.52 & 0.77 \\
\hline & GF & -0.18 & -0.01 & -0.23 & -0.23 & 0.00 & -0.35 & 0.21 & 0.13 \\
\hline \multirow[t]{2}{*}{$\mathrm{An} / \mathrm{Ci}$} & A & -0.65 & 0.24 & -0.62 & -0.84 & -0.33 & 0.25 & -0.06 & -0.37 \\
\hline & GF & 0.27 & 0.59 & 0.09 & 0.20 & 0.19 & 0.35 & -0.38 & 0.02 \\
\hline \multirow[t]{2}{*}{$\mathrm{An} / \mathrm{gs}$} & A & -0.69 & 0.30 & -0.59 & -0.87 & -0.57 & 0.10 & -0.51 & -0.77 \\
\hline & GF & 0.01 & -0.09 & 0.14 & 0.05 & -0.12 & -0.04 & -0.15 & -0.03 \\
\hline \multirow[t]{2}{*}{$\Psi_{L}$} & A & 0.40 & -0.29 & 0.26 & 0.64 & 0.14 & -0.43 & 0.53 & 0.56 \\
\hline & GF & 0.08 & 0.73 & -0.01 & -0.03 & 0.19 & 0.27 & -0.03 & 0.17 \\
\hline \multirow[t]{2}{*}{$\sim F^{\prime}$} & A & -0.43 & -0.26 & -0.08 & 0.11 & -0.20 & -0.14 & 0.32 & 0.20 \\
\hline & GF & 0.23 & -0.38 & 0.27 & 0.35 & 0.51 & 0.45 & 0.52 & 0.46 \\
\hline \multirow[t]{2}{*}{ Chl } & A & 0.34 & 0.07 & 0.26 & 0.10 & 0.26 & 0.66 & -0.41 & 0.03 \\
\hline & GF & -0.06 & 0.14 & -0.03 & -0.29 & -0.04 & 0.48 & -0.39 & -0.41 \\
\hline \multirow[t]{2}{*}{ ETRmax } & A & -0.13 & -0.06 & 0.07 & -0.32 & 0.08 & 0.49 & -0.38 & -0.22 \\
\hline & GF & -0.12 & 0.56 & -0.16 & -0.39 & 0.17 & 0.41 & -0.53 & -0.21 \\
\hline \multirow[t]{2}{*}{$\mathrm{Fm}^{\prime}$} & A & -0.03 & -0.48 & 0.06 & 0.30 & -0.13 & 0.07 & 0.37 & 0.12 \\
\hline & GF & 0.33 & -0.25 & 0.26 & 0.38 & 0.70 & 0.54 & 0.42 & 0.52 \\
\hline \multirow[t]{2}{*}{ Fo } & A & -0.23 & -0.15 & 0.00 & -0.16 & -0.16 & -0.58 & 0.69 & 0.18 \\
\hline & GF & -0.15 & -0.13 & -0.01 & -0.03 & 0.23 & 0.22 & 0.58 & 0.20 \\
\hline \multirow[t]{2}{*}{$\mathrm{Fv} / \mathrm{Fm}$} & $A$ & -0.04 & 0.02 & 0.08 & -0.32 & 0.22 & 0.53 & -0.68 & -0.24 \\
\hline & GF & -0.11 & 0.02 & -0.21 & -0.22 & -0.01 & 0.09 & -0.48 & -0.25 \\
\hline \multirow[t]{2}{*}{ NPQ } & A & 0.06 & 0.34 & -0.07 & -0.40 & 0.06 & -0.14 & -0.19 & -0.19 \\
\hline & GF & -0.40 & 0.03 & -0.29 & -0.38 & -0.77 & -0.51 & -0.37 & -0.65 \\
\hline \multirow[t]{2}{*}{$Y(I I)$} & A & -0.40 & 0.03 & -0.01 & -0.46 & 0.04 & 0.36 & -0.35 & -0.23 \\
\hline & GF & -0.09 & 0.59 & -0.19 & -0.40 & 0.09 & 0.36 & -0.55 & -0.29 \\
\hline \multirow[t]{2}{*}{$\mathrm{Y}(\mathrm{NO})$} & A & 0.07 & -0.34 & 0.09 & 0.14 & -0.11 & 0.04 & 0.40 & 0.18 \\
\hline & GF & 0.26 & -0.28 & 0.08 & 0.22 & 0.70 & 0.39 & 0.58 & 0.70 \\
\hline \multirow[t]{2}{*}{ Y(NPQ) } & A & 0.04 & 0.30 & -0.03 & -0.30 & 0.11 & -0.25 & -0.18 & -0.06 \\
\hline & GF & -0.29 & -0.10 & -0.21 & -0.24 & -0.68 & -0.59 & -0.17 & -0.44 \\
\hline \multirow[t]{2}{*}{$\Delta^{13} \mathrm{C}$} & A & 0.57 & 0.01 & 0.31 & 0.84 & 0.46 & -0.42 & 0.56 & 0.89 \\
\hline & GF & 0.71 & 0.02 & 0.31 & 0.77 & 0.61 & -0.16 & 0.61 & 0.86 \\
\hline
\end{tabular}

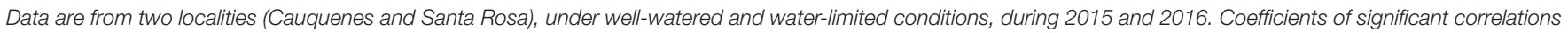
(at $P<0.05$ ) are in bold characters. Abbreviation as in previous tables.

continue assimilating carbon and mobilizing it to the grain, during grain filling.

\section{CONCLUSION}

In field conditions under different environments and water regimes, triticale (cv. Aguacero) has usually higher GY associated with larger numbers of grains per spike and larger kernel weight compared to bread wheat. In terms of tolerance to water deficit, triticale appeared to be more susceptible than wheat, because the reduction of GY under severe water stress compared to wellwatered condition. The physiological characterization indicated that the two species have different strategies; triticale presented higher photosynthetic rates that contributed to increase plant growth and yield in the different environments, whereas wheat showed higher photoprotection system in detriment of assimilate production. Regardless of the water treatment, the contribution of post-anthesis $\mathrm{CO}_{2}$ assimilation to grain filling was higher in triticale. In fact, TKW was positively correlated with An and ETRmax in triticale. The higher An in triticale was linked to improved water use and apparent carboxilation efficiency.

\section{AUTHOR CONTRIBUTIONS}

AM-E, SR-B, FE, and MG performed the evaluations of physiological traits. DC and IM was in charge of the management of field experiments and evaluation of agronomic traits. AdP, AM-E, GL, and IA performed the data analysis. AdP was in charge of the writing up but all the authors contributed to the manuscript. 


\section{FUNDING}

A-ME was supported by FONDECYT Postdoc 3160687. The research was funded by the grants FONDECYT Nos. 1150353 and 1180252, and PIEI "Adaptación de la Agricultura al Cambio Climático (A2C2),” Universidad de Talca.

\section{ACKNOWLEDGMENTS}

We thank Alejandro Castro for technical assistance in field experiments.

\section{REFERENCES}

Araus, J. L., Slafer, G. A., Royo, C., and Serret, M. D. (2008). Breeding for yield potential and stress adaptation in cereals. Crit. Rev. Plant Sci. 27, 377-412. doi: $10.1080 / 07352680802467736$

Arguello, M. N., Mason, R. E., Roberts, T. L., Subramanian, N., Acuña, A., Addison, C. K., et al. (2016). Performance of soft red winter wheat subjected to field soil waterlogging: grain yield and yield components. Field Crop. Res. 194, 57-64. doi: 10.1016/j.fcr.2016.04.040

Bacelar, E. A., Santos, D. L., Moutinho-Pereira, J. M., Gonçalves, B. C., Ferreira, H. F., and Correia, C. M. (2006). Immediate responses and adaptative strategies of three olive cultivars under contrasting water availability regimes: changes on structure and chemical composition of foliage and oxidative damage. Plant Sci. 170, 596-605. doi: 10.1016/j.plantsci.2005.10.014

Bassu, S., Asseng, S., and Richards, R. (2011). Yield benefits of triticale traits for wheat under current and future climates. Field Crop. Res. 4, 14-24. doi: 10.1016/j.fcr.2011.05.020

Bates, L. S., Waldren, R. P., and Teare, I. D. (1973). Rapid determination of free proline for water-stress studies. Plant Soil 39, 205-207. doi: 10.1016/j.dental. 2010.07.006

Beer, S., and Björk, M. (2000). Measuring rates of photosynthesis of two tropical seagrasses by pulse amplitude modulated (PAM) fluorometry. Aquat. Bot. 66, 69-76. doi: 10.1016/S0304-3770(99)00020-0

Beres, B. L., Harker, K. N., Clayton, G. W., Bremer, E., Blackshaw, R. E., and Graf, R. J. (2010). Weed-competitive ability of spring and winter cereals in the northern great plains. Weed Technol. 24, 108-116. doi: 10.1614/WT-D-0900036.1

Björkman, O., and Demmig, B. (1987). Photon yield of $\mathrm{O}_{2}$ evolution and chlorophyll fluorescence characteristics at $77 \mathrm{~K}$ among vascular plants of diverse origins. Planta 170, 489-504. doi: 10.1007/BF00402983

Blum, A. (2009). Effective use of water (EUW) and not water-use efficiency (WUE) is the target of crop yield improvement under drought stress. Field Crop Res. 112, 119-123. doi: 10.1016/j.fcr.2009.03.009

Borrell, A. K., Hammer, G. L., and Douglas, A. C. L. (2000). Does maintaining green leaf area in Sorghum improve yield under drought? I. Leaf growth and senescence. Crop Sci. 40, 1026-1037. doi: 10.2135/cropsci2000. $4041026 \mathrm{x}$

Buckley, T. N. (2017). Modeling stomatal conductance. Plant Physiol. 174, $572-$ 582. doi: $10.1104 /$ pp. 16.01772

Calderini, D., and Dreccer, F. (2002). Choosing Genotype, Sowing Date, and Plant Density for Malting Barley. Barley science. Recent Advances from Molecular Biology to Agronomy of Yield and Quality. New York, NY: Food Products Press, 413-443.

Calderini, D. F., Reynolds, M. P., and Slafer, G. A. (2006). Source-sink effects on grain weight of bread wheat, durum wheat, and triticale at different locations. Aut. J. Agric. Res. 57, 227-233. doi: 10.1071/AR05107

Chaves, M. M., and Oliveira, M. M. (2004). Mechanisms underlying plant resilience to water deficits: prospects for water-saving agriculture. J. Exp. Bot. 55, 23652384. doi: $10.1093 /$ jxb/erh269

del Pozo, A., Castillo, D., Inostroza, L., Matus, I., Méndez, A. M., and Morcuende, R. (2012). Physiological and yield responses of recombinant chromosome substitution lines of barley to terminal drought in a

\section{SUPPLEMENTARY MATERIAL}

The Supplementary Material for this article can be found online at: https://www.frontiersin.org/articles/10.3389/fpls.2019.00404/ full\#supplementary-material

FIGURE S1 | Principal component analysis (PCA) of physiological and agronomic traits determined in triticale (Trit) and wheat (Wh) in different environments. Symbols represent the combination of species, water regime (WW, well-watered; WL, water-limited), site (CAU, Cauquenes; SR, Santa Rosa), and year (2015 and 2106). In (A) biplot of the first two principal components (PC1 and PC2) and the position of the two species on the different environments; in (B) the loading-plots of physiological and productivity traits measurements used in the PCA.

Mediterranean-type environment. Ann. Appl. Biol. 160, 157-167. doi: 10.1111/j.1744-7348.2011.00528.x

del Pozo, A., Matus, I., Serret, M. D., and Araus, J. L. (2014). Agronomic and physiological traits associated with breeding advances of wheat under highproductive Mediterranean conditions. The case of Chile. Environ. Exper. Bot. 103, 180-189. doi: 10.1016/j.envexpbot.2013.09.016

del Pozo, A., Yañez, A., Matus, I. A., Tapia, G., Castillo, D., Sanchez-Jardón, L., et al. (2016). Physiological traits associated with wheat yield potential and performance under water-stress in a Mediterranean environment. Front. Plant Sci. 7:987. doi: 10.3389/fpls.2016.00987

Dolferus, R., Powell, N., Ji, X., Ravash, R., Edlington, J., Oliver, S., et al. (2013). Chapter 8: The physiology of reproductive-stage abiotic stress tolerance in cereals. Molecular Stress Physiology of Plants. New Delhi: Springer, 193-218. doi: 10. 1007/978-81-322-0807-5_8

Drake, P. L., Froend, R. H., and Franks, P. J. (2013). Smaller, faster stomata: scaling of stomatal size, rate of response, and stomatal conductance. J. Exp. Bot. 64, 495-505. doi: 10.1093/jxb/ers347

Eilers, P. H. C., and Peeters, J. C. H. (1988). A model for the relationship between light intensity and the rate of photosynthesis in phytoplankton. Ecol. Modell. 42, 199-215. doi: 10.1016/0304-3800(88)90057-9

Ennajeh, M., Vadel, A. M., Cochard, H., and Khemira, H. (2010). Comparative impacts of water stress on the leaf anatomy of a drought-resistant and a drought-sensitive olive cultivar. J. Hortic. Sci. Biotech. 85, 289-294. doi: 10.1080/ 14620316.2010.11512670

Estrada, F., Escobar, A., Romero-Bravo, S., González-Talice, J., PobleteEcheverría, C., Caligari, P. D. S., et al. (2015). Fluorescence phenotyping in blueberry breeding for genotype selection under drought conditions, with or without heat stress. Sci. Hort. 181, 147-161. doi: 10.1016/j.scienta.2014. 11.004

Estrada-Campuzano, G., Slafer, G. A., and Miralles, D. J. (2012). Differences in yield, biomass and their components between triticale and wheat grown under contrasting water and nitrogen environments. Field Crop Res. 128, 167-179. doi: 10.1016/j.fcr.2012.01.003

Evans, L., Wardlaw, I., and Fischer, R. (1975). Wheat. London: Cambridge University Press.

FAO (2018). FAOSTAT. Rome: FAO.

Farquhar, G. D., Ehleringer, J. R., and Hubick, K. T. (1989). Carbon isotope discrimination and photosynthesis. Annu. Rev. Plant Physiol. Plant Mole. Biol. 40, 503-537. doi: 10.1146/annurev.pp.40.060189.002443

Ferrante, A., Cartelle, J., Savin, R., and Slafer, G. A. (2017). Yield determination, interplay between major components and yield stability in a traditional and a contemporary wheat across a wide range of environments. Field Crop Res. 203, 114-127. doi: 10.1016/j.fcr.2016.12.028

Finlay, K., and Wilkinson, G. (1963). The analysis of adaptation in a plant-breeding programme. Aust. J. Agric. Res. 14, 742-754. doi: 10.1071/AR9630742

Fracheboud, Y., and Leipner, J. (2003). Chapter 4: The Application of Chlorophyll Fluorescence to Study Light, Temperature, and drought stress. Practical applications of Chlorophyll Fluorescence in plant Biology. Boston, MA: Springer, 125-150. doi: 10.1007/978-1-4615-0415-3_4

Franks, P. J., and Beerling, D. J. (2009). Maximum leaf conductance driven by $\mathrm{CO}_{2}$ effects on stomatal size and density over geologic time. Proc. Natl. Acad. Sci. U.S.A. 106, 10343-10347. doi: 10.1073/pnas.0904209106 
Franks, P. J., Doheny-Adams, T. W., Britton-Harper, Z. J., and Gray, J. E. (2015). Increasing water-use efficiency directly through genetic manipulation of stomatal density. New Phytol. 207, 188-195. doi: 10.1111/nph.13347

Giday, H., Kjaer, K. H., Fanourakis, D., and Ottosen, C. O. (2013). Smaller stomata require less severe leaf drying to close: a case study in Rosa hydrida. J. Plant Physiol. 170, 1309-1316. doi: 10.1016/j.jplph.2013.04.007

Giunta, F., Motzo, R., and Deidda, M. (1993). Effect of drought on yield and yield components of durum wheat and triticale in a Mediterranean environment. Field Crop. Res. 33, 399-409. doi: 10.1016/0378-4290(93)90161-F

Gous, P. W., Hasjim, J., Franckowiak, J., Fox, G. P., and Gilbert, R. G. (2013). Barley genotype expressing "stay-green"-like characteristics maintains starch quality of the grain during water stress condition. J. Cereal Sci. 58, 414-419. doi: 10.1016/j.jcs.2013.08.002

Guerfel, M., Baccouri, O., Boujnah, D., Chaïbi, W., and Zarrouk, M. (2009). Impacts of water stress on gas exchange, water relations, chlorophyll content and leaf structure in the two main Tunisian olive (Olea europaea L.) cultivars. Sci. Hort. 119, 257-263. doi: 10.1016/j.scienta.2008.08.006

Harbinson, J., and Rosenqvist, E. (2003). Chapter 1: An Introduction to Chlorophyll Fluorescence. Practical Applications of Chlorophyll Fluorescence in Plant Biology. Boston, MA: Springer, 1-29.

Hetherington, A. M., and Woodward, F. I. (2003). The role of stomata in sensing and driving environmental change. Nature 424, 901. doi: 10.1038/nature01843

Hochman, Z., Gobbett, D. L., and Horan, H. (2017). Climate trends account for stalled wheat yields in Australia since 1990. Glob. Change Biol. 23, 2071-2081. doi: $10.1111 /$ gcb.13604

Hughes, J., Hepworth, C., Dutton, C., Dunn, J. A., Hunt, L., Stephens, J., et al. (2017). Reducing stomatal density in barley improves drought tolerance without impacting on yield. Plant Physiol. 174, 776-787. doi: 10.1104/pp.16. 01844

Hura, T., Hura, K., and Grzesiak, M. T. (2009). The usefulness of the chlorophyll fluorescence parameters in harvest prediction in 10 genotypes of winter triticale under optimal growth conditions. Plant Biosyst. 143, 496-503. doi: 10.1080/ 11263500903178083

Huseynova, I. M., Rustamova, S. M., Suleymanov, S. Y., Aliyeva, D. R., Mammadov, A. C., and Aliyev, J. A. (2016). Drought-induced changes in photosynthetic apparatus and antioxidant components of wheat (Triticum durum Desf.) varieties. Photosynth. Res. 130, 215-223. doi: 10.1007/s11120-0160244-z

Inskeep, W. P., and Bloom, P. R. (1985). Extinction coefficients of chlorophyll a and b in N,N-Dimethylformamide and 80\% acetone. Plant Physiol. 77, 483-485. doi: $10.1104 /$ pp.77.2.483

Kavanagh, V., Hills, M., Goyal, A., Randhawa, H., Topinka, A. K., Eudes, F., et al. (2013). Molecular markers as a complementary tool in risk assessments: quantifying interspecific gene flow from triticale to spring wheat and durum wheat. Transgenic Res. 22, 767-778. doi: 10.1007/s11248-012-9683-2

Khan, M., Khan, F. U., Saleem, Z., and Khattak, S. G. (2015). Comparative suitability of wheat, triticale, barley, and oat in the ecology of Kohat, Pakistan. J. Biol. Agric. Health 5, 202-204.

Kholová, J., Murugesan, T., Kaliamoorthy, S., Malayee, S., Baddam, R., Hammer, G. L., et al. (2014). Modelling the effect of plant water use traits on yield and stay-green expression in sorghum. Funct. Plant Biol. 41, 1019-1034. doi: 10.1071/FP13355

Klughammer, C., and Schreiber, U. (2008). Complementary PSII quantum yields calculated from simple fluorescence parameters measured by PAM fluorometry and the saturation pulse method. PAM Appl. Notes 1, 201-247.

Kumar, T., Khan, M. R., Abbas, Z., and Ali, G. M. (2014). Genetic improvement of sugarcane for drought and salinity stress tolerance using Arabidopsis vacuolar pyrophosphatase (AVP1) gene. Mol. Biotechnol 56, 199-209. doi: 10.1007/ s12033-013-9695-z

Latini, A., Sperandei, M., Cantale, C., Arcangeli, C., Ammar, K., and Galeffi, P. (2013). Variability and expression profile of the DRF1 gene in four cultivars of durum wheat and one triticale under moderate water stress conditions. Planta 237, 967-978. doi: 10.1007/s00425-012-1816-6

Lawlor, D. W., and Tezara, W. (2009). Causes of decreased photosynthetic rate and metabolic capacity in water-deficient leaf cells: a critical evaluation of mechanisms and integration of processes. Ann. Bot. 103, 561-579. doi: 10.1093/ aob/mcn 244
Lawson, T., and Blatt, M. R. (2014). Stomatal size, speed, and responsiveness impact on photosynthesis and water use efficiency. Plant Physiol. 164, 1556-1570. doi: $10.1104 /$ pp.114.237107

Liu, H., Able, A. J., and Able, J. A. (2017). Genotypic water-deficit stress responses in durum wheat: association between physiological traits, microRNA regulatory modules and yield components. Func. Plant Biol. 44, 538-551. doi: 10.1071/ FP16294

Lonbani, M., and Arzani, A. (2011). Morpho-physiological traits associated with terminal drought stress tolerance in triticale and wheat. Agron. Res. 9, 315-329.

López-Castañeda, C., and Richards, R. A. (1994). Variation in temperate cereals in rainfed environments I. Grain yield, biomass and agronomic characteristics. Field Crops Res. 37, 51-62. doi: 10.1016/0378-4290(94)90081-7

Mathew, I., Shimelis, H., Mwadzingeni, L., Zengeni, R., Mutema, M., and Chaplot, V. (2018). Variance components and heritability of traits related to root: shoot biomass allocation and drought tolerance in wheat. Euphytica 214:225. doi: 10.1007/s10681-018-2302-4

Maydup, M. L., Antonietta, M., Guiamet, J. J., Graciano, C., López, J. R., and Tambussi, E. A. (2010). The contribution of ear photosynthesis to grain filling in bread wheat (Triticum aestivum L.). Field Crop Res. 119, 48-58. doi: 10.1093/ jxb/eru298

Maydup, M. L., Antonietta, M., Guiamet, J. J., and Tambussi, E. A. (2012). The contribution of green parts of the ear to grain filling in old and modern cultivars of bread wheat (Triticum aestivum L.): evidence for genetic gains over the past century. Field Crop Res. 134, 208-215. doi: 10.1016/j.fcr.2012.06.008

McAusland, L., Vialet-Chabrand, S., Davey, P., Baker, N. R., Brendel, O., and Lawson, T. (2016). Effects of kinetics of light-induced stomatal responses on photosynthesis and water-use efficiency. New Phytol. 211, 1209-1220. doi: 10. 1111/nph.14000

Mellado, Z., Madariaga, B., and Matus, T. (2005). Aguacero-INIA, nuevo cultivar de triticale de primavera para Chile. Agric. Téc. 65, 90-95. doi: 10.4067/S036528072005000100010

Méndez, A. M., Castillo, D., del Pozo, A., Matus, I., and Morcuende, R. (2011). Differences in stem soluble carbohydrate contents among recombinant chromosome substitution lines (RCSLs) of barley under drought in a Mediterranean-type environment. Agron. Res. 9:433.

Merah, O., Deléens, E., and Monneveux, P. (2001). Relationships between carbon isotope discrimination, dry matter production, and harvest index in durum wheat. J. Plant Physiol. 158, 723-729. doi: 10.1078/0176-1617-00273

Monneveux, P., Rekika, D., Acevedo, E., and Merah, O. (2006). Effect of drought on leaf gas exchange, carbon isotope discrimination, transpiration efficiency and productivity in field grown durum wheat genotypes. Plant Sci. 170, 867-872. doi: $10.1016 /$ j.plantsci.2005.12.008

Moran, R., and Porath, D. (1980). Chlorophyll determination in intact tissues using N,N-Dimethylformamide. Plant Physiol. 65, 478-479. doi: 10.1104/pp.65.3.478

Motzo, R., Pruneddu, G., and Giunta, F. (2013). The role of stomatal conductance for water and radiation use efficiency of durum wheat and triticale in a Mediterranean environment. Eur. J. Agron. 44, 87-97. doi: 10.1016/j.eja.2012. 09.002

Motzo, R., Pruneddu, G., Virdis, A., and Giunta, F. (2015). Triticale vs durum wheat: a performance comparison in a Mediterranean environment. Field Crop Res. 180, 63-71. doi: 10.1016/j.fcr.2015.05.007

Munjonji, L., Ayisi, K. K., Vandewalle, B., Haesaert, G., and Boeckx, P. (2017). "Carbon isotope discrimination as a surrogate of grain yield in drought stressed triticale," in Climate Change Adaptation in Africa, eds W. Leal Filho, S. Belay, J. Kalangu, W. Menas, P. Munishi, and K. Musiyiwa (Cham: Springer), 603-615.

ODEPA (2018). Oficina de Estudios y Políticas Agrarias, Estadísticas productivas, Chile. Available at: https://www.odepa.gob.cl/estadisticas-del-sector/ estadisticas-productiva

Peltonen-Sainio, P., Kangas, A., Salo, Y., and Jauhiainen, L. (2007). Grain number dominates grain weight in temperate cereal yield determination: evidence based on 30 years of multi-location trials. Field Crop Res. 100, 179-188. doi: 10.1016/ j.fcr.2006.07.002

Pinheiro, C., António, C., Ortuño, M. F., Dobrev, P. I., Hartung, W., ThomasOates, J., et al. (2011). Initial water deficit effects on Lupinus albus photosynthetic performance, carbon metabolism, and hormonal balance: metabolic reorganization prior to early stress responses. J. Exp. Bot. 62, 49654974. doi: 10.1093/jxb/err194 
Planchon, C. (1979). Photosynthesis, transpiration, resistance to $\mathrm{CO}_{2}$ transfer, and water efficiency of flag leaf of bread wheat, durum wheat and triticale. Euphytica 28, 403-408. doi: 10.1007/BF00056598

Ramanjulu, S., and Bartels, D. (2002). Drought and desiccation induced modulation of gene expression in plants. Plant Cell Environ. 25, 141-151. doi: 10.1046/j.0016-8025.2001.00764.x

Raven, J. A. (2014). Speedy small stomata? J. Exp. Bot. 65, 1415-1424. doi: 10.1093/ jxb/eru032

Roohi, E., Tahmasebi Sarvestani, Z., Modarres-Sanavy, S. A. M., and Siosemardeh, A. (2013). Comparative study on the effect of soil water stress on photosynthetic function of triticale, bread wheat, and barley. J. Agr. Sci. Tech. 15, 215-225.

Roostaei, M., Mohammadi, S. A., Amri, A., Majidi, E., Nachit, M., and Haghparast, R. (2011). Chlorophyll fluorescence parameters and drought tolerance in a mapping population of winter bread wheat in the highlands of Iran. Russ. J. Plant Physiol. 58, 351-358. doi: 10.1134/S102144371 102018X

Roques, S. E., Kindred, D. R., and Clarke, S. (2017). Triticale out-performs wheat on range of UK soils with a similar nitrogen requirement. J. Agric. Sci. 155, 261-281. doi: 10.1017/S0021859616000356

Sanchez-Bragado, R., Elazab, A., Zhou, B., Serret, M. D., Bort, J., Nieto-Taladriz, M. T., et al. (2014). Contribution of the ear and the flag leaf to grain filling in durum wheat inferred from the carbon isotope signature: genotypic and growing conditions effects. J. Integr. Plant Biol. 56, 444-454. doi: 10.1111/jipb. 12106

Scherner, F., Ventura, R., Barufi, J. B., and Horta, P. A. (2013). Salinity critical threshold values for photosynthesis of two cosmopolitan seaweed species: providing baselines for potential shifts on seaweed assemblages. Mar. Environ. Res. 91, 14-25. doi: 10.1016/j.marenvres.2012.05.007

Schnyder, H. (1993). The role of carbohydrate storage and redistribution in the source-sink relations of wheat and barley during grain fillinga review. New Phytol. 123, 233-245. doi: 10.1111/j.1469-8137.1993. tb03731.x

Shahinnia, F., Le Roy, J., Laborde, B., Sznajder, B., Kalambettu, P., Mahjourimajd, S., et al. (2016). Genetic association of stomatal traits and yield in wheat grown in low rainfall environments. BMC Plant Biol. 16:150. doi: 10.1186/s12870-016-0838-9

Sharma, D. K., Andersen, S. B., Ottosen, C. O., and Rosenquist, E. (2015). Wheat cultivars selected for high Fv/Fm under heat stress maintain high photosynthesis, total chlorophyll, stomatal conductance, transpiration and dry matter. Physiol. Plant. 153, 284-298. doi: 10.1111/ppl. 12245

Sikder, S., Foulkes, J., West, H., De Silva, J., Gaju, O., Greenland, A., et al. (2015). Evaluation of photosynthetic potential of wheat genotypes under drought condition. Photosynthetica 53, 47-54. doi: 10.1007/s11099-015-0082-9

Sinha, S. K., Aggarwal, P. K., Chaturvedi, G. S., Singh, A. K., and Kailasnathan, K. (1986). Performance of wheat and triticale cultivars in a variable soil-water environment I. Grain yield stability. Field Crop Res. 13, 289-299. doi: 10.1016/ 0378-4290(86)90031-6

Sio-Se Mardeh, A., Ahmadi, A., Poustini, K., and Mohammadi, V. (2006). Evaluation of drought resistance indices under various environmental conditions. Field Crop Res. 98, 222-229. doi: 10.1016/j.fcr.2006.02.001

Slafer, G. A., Savin, R., and Sadras, V. O. (2014). Coarse and fine regulation of wheat yield components in response to genotype and environment. Field Crop Res. 157, 71-83. doi: 10.1016/j.fcr.2013.12.004
Sofo, A. (2011). Drought stress tolerance and photoprotection in two varieties of olive tree. Acta Agric. Scand. Sect. B. Soil Plant Sci. 61, 711-720. doi: 10.1080/ 09064710.2010 .545071

Stanca, A. M., Romagosa, I., Takeda, K., Lundborg, T., Terzi, V., and Cattivelli, L. (2003). Chapter 9: Diversity in Abiotic Stress Tolerances. Diversity in Barley (Hordeum vulgare). Amsterdam: Elsevier, 179-199. doi: 10.1016/S01687972(03)80011-7

Stella, T., Bregaglio, S., and Confalonieri, R. (2016). A model to simulate the dynamics of carbohydrate remobilization during rice grain filling. Ecol. Modell. 320, 366-371. doi: 10.1016/j.ecolmodel.2015.10.026

Tambussi, E. A., Bort, J., and Araus, J. L. (2007). Water use efficiency in C3 cereals under Mediterranean conditions: a review of physiological aspects. Ann. Appl. Biol. 150, 307-321. doi: 10.1111/j.1744-7348.2007.00143.x

Trnka, M., Rötter, R. P., Ruiz-Ramos, M., Kersebaum, K. C., Olesen, J. E., Žalud, Z., et al. (2014). Adverse weather conditions for European wheat production will become more frequent with climate change. Nat. Clim. Change 4, 637-643. doi: $10.1038 /$ nclimate2242

Ugarte, C., Calderini, D. F., and Slafer, G. A. (2007). Grain weight and grain number responsiveness to pre-anthesis temperature in wheat, barley and triticale. Field Crop Res. 100, 240-248. doi: 10.1016/j.fcr.2006.07.010

Villegas, D., Casadesús, J., Atienza, S. G., Martos, V., Maalouf, F., Karam, F., et al. (2010). Tritordeum, wheat and triticale yield components under multi-local mediterranean drought conditions. Field Crop Res. 116, 68-74. doi: 10.1016/j. fcr.2009.11.012

Winzeler, M., McCullough, D. E., and Hunt, L. A. (1989). Leaf gas exchange and plant growth of winter rye, triticale, and wheat under contrasting temperature regimes. Crop Sci. 29, 1256-1260. doi: 10.2135/cropsci1989. 0011183X002900050033x

Xue, G.-P., McIntyre, C. L., Rattey, A. R., van Herwaarden, A. F., and Shorter, R. (2009). Use of dry matter content as a rapid and low-cost estimate for ranking genotypic differences in water-soluble carbohydrate concentrations in the stem and leaf sheath of Triticum aestivum. Crop Pasture Sci. 60, 51-59. doi: 10.1071/ CP08073

Yáñez, A., Tapia, G., Guerra, F., and del Pozo, A. (2017). Stem carbohydrate dynamics and expression of genes involved in fructan accumulation and remobilization during grain growth in wheat (Triticum aestivum L.) genotypes with contrasting tolerance to water stress. PLoS One 12:e0177667. doi: 10.1371/ journal.pone.0177667

Yang, J., and Zhang, J. (2006). Grain filling of cereals under soil drying. New Phytol. 169, 223-236. doi: 10.1111/j.1469-8137.2005.01597.x

Zhang, G., Venkatachalam, M., and Hamaker, B. R. (2006). Structural basis for the slow digestion property of native cereal starches. Biomacromolecules 7 , 3259-3266. doi: 10.1021/bm060343a

Conflict of Interest Statement: The authors declare that the research was conducted in the absence of any commercial or financial relationships that could be construed as a potential conflict of interest.

Copyright (c) 2019 Méndez-Espinoza, Romero-Bravo, Estrada, Garriga, Lobos, Castillo, Matus, Aranjuelo and del Pozo. This is an open-access article distributed under the terms of the Creative Commons Attribution License (CC BY). The use, distribution or reproduction in other forums is permitted, provided the original author(s) and the copyright owner(s) are credited and that the original publication in this journal is cited, in accordance with accepted academic practice. No use, distribution or reproduction is permitted which does not comply with these terms. 